\title{
Synthetic aspects of tetraorganotins and organotin(IV) halides
}

\author{
Sander H.L. Thoonen ${ }^{a}$, Berth-Jan Deelman ${ }^{\text {b,* }}$, Gerard van Koten ${ }^{\text {a }}$ \\ ${ }^{a}$ Department of Metal-Mediated Synthesis, Debye Institute, Utrecht University, Padualaan 8, 3584 CH Utrecht, The Netherlands \\ ${ }^{\mathrm{b}}$ ATOFINA Vlissingen B.V., P.O. Box 70, 4380 AB Vlissingen, The Netherlands
}

Received 15 April 2003; accepted 20 March 2004

Dedicated to Prof. dr. G.J.M. van der Kerk on the occasion of his 90th birthday in recognition of his great and pioneering contributions to organotin chemistry and applications

\begin{abstract}
Organotin(IV) compounds are being used for many applications, e.g., as stabilizers in PVC, in anti-fouling paints and coatings for the protection of ship hulls and as precursors for $\mathrm{SnO}_{2}$-coatings on glass. Tetraorganotins and especially organotin(IV) halides often serve as synthetic precursors. A wide range of methods for the synthetic preparation of these compounds has been developed since the 1940s. This review gives an overview of the available routes for the preparation of organotin(IV) compounds and discusses their selectivity and yield. In particular, monoorganotin trihalides are often not accessible in high yield.
\end{abstract}

(c) 2004 Elsevier B.V. All rights reserved.

Keywords: Tetraorganotins; Organotin halides; Selective synthesis

\section{Introduction}

The synthesis of the first organotin compound, diethyltin diiodide, was reported by Frankland in 1849 [1]. From the 1940s onwards, organotin compounds became commercially relevant when the production of polyvinyl chloride (PVC) began to expand. Addition of di- and trimercaptides such as dialkyltin di(isooctylthioglycolate) $\left(\mathrm{R}_{2} \mathrm{Sn}\left(\mathrm{SCH}_{2} \mathrm{COOC}_{8} \mathrm{H}_{17}^{\mathrm{i}}\right)_{2} ; \mathrm{R}=\mathrm{Me}, n\right.$-Bu, $n$-Oct $)$ and alkyltin tris(isooctylthioglycolate) $\left(\mathrm{RSn}\left(\mathrm{SCH}_{2} \mathrm{CO}\right.\right.$ $\left.\mathrm{OC}_{8} \mathrm{H}_{17}^{\mathrm{i}}\right)_{3} ; \mathrm{R}=\mathrm{Me}, n$-Bu, $n$-Oct) inhibit the dehydrochlorination reaction by exchanging their anionic $\mathrm{SR}^{-}$ group with the allylic $\mathrm{Cl}$ atoms in the polymer [2]. Furthermore, they scavenge the liberated $\mathrm{HCl}$. As a result, the photolytic and thermal degradation of PVC is slowed down [3]. The use of these compounds as PVC stabilizer is still the largest application of organotins today.

The biocidal properties of organotins in general and triorganotins in particular were discovered by Van der Kerk at the TNO Institute, Utrecht in the late 1950s [4].

\footnotetext{
${ }^{*}$ Corresponding author. Tel.: +31-113-617000; fax: +31-113-612984

E-mail address: berth-jan.deelman@atofina.com (B.-J. Deelman).
}

The first biocidal application was the use of bis(tributyltin) oxide (TBTO) as timber preservative [5]. Wood impregnated with TBTO is effectively protected against fungi and insects. Because of the very low solubility of TBTO in water, wood preservation was carried out with TBTO dissolved in organic solvents such as kerosene. The use of water as solvent became possible by the addition of quaternary ammonium salts and by the development of water soluble biocides such as trialkyltin methanesulphonates [6] and tributyl mesylimide [7]. The second major biocidal application of triorganotins has been in anti-fouling paints and coatings for the protection of ship hulls from aquatic organisms. Growth of aquatic organisms on vessel hulls creates roughness which causes an increase in the fuel consumption [8]. For example, it was estimated that the use of antifouling paints saved the US Navy an estimated 150 million US dollars of fuel annually and maybe more importantly, reduces $\mathrm{CO}_{2}$ emission and consumption of our fossil fuel feedstock [9]. Most often applied are tributyltin (TBT) based antifouling systems which have an acute toxicity to target organisms. Due to the worldwide use of TBT, high concentrations of TBTO are found in different compartments of aquatic 
environments such as sea-water $\left(10^{-6}\right.$ to $\left.10^{-3} \mathrm{mg} \mathrm{kg}^{-1}\right)$, sediment $\left(10^{-3}\right.$ to $\left.10^{1} \mathrm{mg} \mathrm{kg}^{-1}\right)$ and mussels $\left(10^{-1}\right.$ to $10^{2}$ $\mathrm{mg} \mathrm{kg}^{-1}$ ) [10]. The distribution [10d,11] and effects of organotins on marine and fresh-water environments [10d,12] have been studied extensively. These studies have revealed that tributyltin species at concentrations of $1 \mathrm{ng} \mathrm{1^{-1 }}$ can induce "imposex" in sea snails [10d]. As a result, reproduction fails and the population of snails in dogwhelks declined dramatically [13]. This adverse effect has resulted in a world-wide ban on the application of TBT by January 2003 by the International Maritime Organization (IMO) [14]. Meanwhile, alternative antifouling systems based on metallic copper and organic boosters have been developed [9]. However, their fate and toxic effects on the marine environment as well as their antifouling effectiveness are not well studied yet.

An important application of monoalkyltins like $n$ butyltin trichloride, is their use as precursor for the deposition of thin tin(IV) oxide layers (up to $100 \mathrm{~nm}$ thick) on glass bottles. The coating is formed from the precursor by chemical vapor deposition (CVD) at the hot glass surface (typically $500-600{ }^{\circ} \mathrm{C}$ ) where the precursor pyrolyses to tin(IV) oxide. The coating increases the impact resistance, so that lighter and cheaper glass bottles can be produced. The tin(IV) oxide layer also improves the adherence of a lubricant film which is applied to reduce the scuff resistance of the glassware. Thicker tin(IV) oxide layers (100-1000 $\mathrm{nm}$ ) cause iridescent appearance on the glass surface and are used for decorative purposes [15]. Layers thicker than $1 \mu \mathrm{m}$ are being applied as conductive films for electronics [16].

In addition to the applications discussed so far, organotins are also used as catalysts for the production of polyurethanes and silicones, as potential anti tumour agents and as disinfectants $[16,17]$.

Organotin compounds differ widely in their acute toxicity. Some of them are highly toxic while others show hardly any toxic effects (Table 1).

Table 1

LD50 value ( $\mathrm{mg} \mathrm{kg}^{-1}$, oral rat) of several organotins [18]

\begin{tabular}{llll}
\hline $\mathrm{R}$ & Methyl & Butyl & Octyl \\
\hline $\mathrm{R}_{4} \mathrm{Sn}$ & $195-331$ & $>4000$ & 50,000 \\
$\mathrm{R}_{3} \mathrm{SnCl}$ & 13 & 60 & n.a. \\
$\mathrm{R}_{2} \mathrm{SnCl}_{2}$ & 74 & 129 & 5500 \\
$\mathrm{RSnCl}_{3}$ & 1370 & 2140 & $2400-3800$ \\
\hline
\end{tabular}

${ }^{a}$ n.a., not available.

Table 2

Synthesis of symmetric tetraorganotins $\mathrm{R}_{4} \mathrm{Sn}$

\begin{tabular}{|c|c|c|c|c|}
\hline Method & $\mathrm{R}$ & Conditions & Yield & References \\
\hline $\mathrm{SnCl}_{4}+4 \mathrm{RMgCl}$ & $\begin{array}{l}\text { Me, Et, } n \text {-Pr, } n \text {-Bu, } \\
n \text { - Pent, } n \text {-Hex, } n \text {-Oct } \\
n \text {-Pr } \\
\mathrm{Me} \\
\text { Et } \\
\text { Allyl } \\
\text { Ph } \\
i \text {-Bu } \\
n \text {-Oct } \\
\text { Vinyl }\end{array}$ & $\begin{array}{l}\mathrm{Et}_{2} \mathrm{O}, \text { toluene } \\
", \\
n-\mathrm{Bu}_{2} \mathrm{O} \\
\mathrm{Et}_{2} \mathrm{O} \\
" \\
" \\
\mathrm{NaCl}, n-\mathrm{Bu}_{2} \mathrm{O} \\
\mathrm{Et}_{2} \mathrm{O}, \text { heptane } \\
\text { THF }\end{array}$ & $\begin{array}{l}83-98 \\
81 \\
82-91 \\
85-96 \\
53-85 \\
75-81 \\
87 \\
88 \\
82\end{array}$ & $\begin{array}{l}{[30]} \\
{[33]} \\
{[27,29,37]} \\
{[31,32]} \\
{[28,39]} \\
{[42,43]} \\
{[57]} \\
{[36]} \\
{[38]}\end{array}$ \\
\hline $\mathrm{SnCl}_{4}+2 \mathrm{R}_{2} \mathrm{Mg}$ & $n$-Bu, $n$-Oct & heptane & $83-95$ & [35] \\
\hline $\mathrm{SnCl}_{4}+2 \mathrm{R}_{2} \mathrm{Zn}$ & $\mathrm{Ph}$ & $\mathrm{Et}_{2} \mathrm{O}$, toluene & 91 & {$[52]$} \\
\hline $3 \mathrm{SnCl}_{4}+4 \mathrm{R}_{3} \mathrm{Al}$ & $\begin{array}{l}\mathrm{Me}, \mathrm{Et}, n \text {-Bu, } i \text {-Bu, } n \text {-Oct } \\
\mathrm{Et} \\
\mathrm{Et}, n \text {-Bu } \\
n \text {-Bu, } n \text {-Oct } \\
i \text {-Bu } \\
\mathrm{Et} \\
i \text {-Bu }\end{array}$ & $\begin{array}{l}\mathrm{Et}_{2} \mathrm{O} \\
\mathrm{NaCl}_{2} \mathrm{CH}_{2} \mathrm{Cl}_{2} \\
n-\mathrm{Bu}_{2} \mathrm{O} \\
\mathrm{CH}_{2} \mathrm{Cl}_{2} \\
\mathrm{KCl} \\
\mathrm{NaCl}, n-\mathrm{Bu}_{2} \mathrm{O}\end{array}$ & $\begin{array}{l}90-98 \\
97 \\
94-97 \\
90-92 \\
92 \\
94 \\
87\end{array}$ & $\begin{array}{l}{[55]} \\
{[54]} \\
{[59]} \\
{[54,55]} \\
{[53]} \\
{[60]} \\
{[57]}\end{array}$ \\
\hline $\mathrm{SnCl}_{4}+4 \mathrm{Na}\left[\mathrm{AlRCl}_{3}\right]$ & $\mathrm{Me}$ & & 95 & {$[61,62]$} \\
\hline $\mathrm{SnCl}_{4}+4 \mathrm{RCl}$ & $\begin{array}{l}n \text {-Bu } \\
n \text {-Oct } \\
\mathrm{Ph}\end{array}$ & $\begin{array}{l}\mathrm{Na} \text {, petroleum } \\
\text { Na, benzene }\end{array}$ & $\begin{array}{l}91 \\
71 \\
80\end{array}$ & $\begin{array}{l}{[48]} \\
{[47]} \\
{[50]}\end{array}$ \\
\hline $\mathrm{R}_{2} \mathrm{SnCl}_{2}+2 \mathrm{RCl}$ & $n$-Bu & Na, xylene & 87 & [46] \\
\hline $\mathrm{R}_{2} \mathrm{SnCl}_{2}+\mathrm{Zn}$ & $n$-Bu & $\mathrm{Zn}, \mathrm{Et}_{3} \mathrm{~N}$ & 35 & [63] \\
\hline $\mathrm{R}_{2} \mathrm{SnCl}_{2}+2 \mathrm{Ph}_{5} \mathrm{Sb}$ & $\mathrm{Ph}$ & Toluene & 95 & [64] \\
\hline
\end{tabular}


Table 3

Synthesis of mixed tetraorganotins $\mathrm{R}_{3} \mathrm{SnR}^{\prime}$ and $\mathrm{R}_{2} \mathrm{SnR}_{2}^{\prime a}$

\begin{tabular}{|c|c|c|c|c|c|}
\hline Method & $\mathrm{R}$ & $\mathrm{R}^{\prime}$ & Conditions & Yield & References \\
\hline $\mathrm{R}_{2} \mathrm{SnX}_{2}+2 \mathrm{R}^{\prime} \mathrm{MgX}$ & $\begin{array}{l}\mathrm{Me}, \mathrm{X}=\mathrm{Br} \\
\mathrm{Me} \\
\mathrm{Me} \\
n \text { - } \mathrm{Bu} \\
\mathrm{Ph}\end{array}$ & $\begin{array}{l}n \text {-Pent } \\
n \text {-Dec } \\
n-\mathrm{C}_{18} \mathrm{H}_{37} \\
\text { Vinyl } \\
\text { Allyl }\end{array}$ & $\begin{array}{l}\mathrm{Et}_{2} \mathrm{O} \\
\mathrm{THF} \\
, " \\
, \\
,\end{array}$ & $\begin{array}{l}95 \\
98 \\
96 \\
85-89 \\
98\end{array}$ & $\begin{array}{l}{[68]} \\
{[71]} \\
{[71]} \\
{[72,73]} \\
{[71]}\end{array}$ \\
\hline $\mathrm{R}_{2} \mathrm{SnCl}_{2}+2 \mathrm{R}_{5}^{\prime} \mathrm{Sb}$ & $\begin{array}{l}\mathrm{Me} \\
\mathrm{Et} \\
\mathrm{Bu} \\
\mathrm{Bu}\end{array}$ & $\begin{array}{l}\mathrm{Ph} \\
\mathrm{Ph} \\
\mathrm{Ph} \\
p \text {-Tol }\end{array}$ & $\begin{array}{l}\text { Toluene } \\
\text { ", } \\
\text { ", }\end{array}$ & $\begin{array}{l}93 \\
93 \\
87 \\
94\end{array}$ & $\begin{array}{l}{[64]} \\
{[64]} \\
{[64]} \\
{[64]}\end{array}$ \\
\hline $\mathrm{R}_{2} \mathrm{SnCl}_{2}+\mathrm{R}^{\prime} \mathrm{Li}$ & $\mathrm{Bz}$ & $\mathrm{Ph}$ & $\mathrm{Et}_{2} \mathrm{O}$ & 83 & [66] \\
\hline $\mathrm{R}_{3} \mathrm{SnCl}+\mathrm{R}^{\prime} \mathrm{MgX}$ & $\begin{array}{l}\mathrm{Me} \\
n-\mathrm{Bu} \\
\mathrm{Cy} \\
\mathrm{Cy}\end{array}$ & $\begin{array}{l}n \text {-Oct } \\
\text { Vinyl } \\
m \text { - } \mathrm{MeC}_{6} \mathrm{H}_{4} \\
p-\mathrm{Bu}^{t} \mathrm{C}_{6} \mathrm{H}_{4}\end{array}$ & $\begin{array}{l}\mathrm{Et}_{2} \mathrm{O} \\
" \\
" \\
"\end{array}$ & $\begin{array}{l}98 \\
85 \\
88 \\
90\end{array}$ & $\begin{array}{l}{[70]} \\
{[72]} \\
{[65]} \\
{[65]}\end{array}$ \\
\hline $\mathrm{R}_{3} \mathrm{SnCl}+\mathrm{R}_{5}^{\prime} \mathrm{Sb}$ & $\begin{array}{l}\mathrm{Me} \\
\mathrm{Me} \\
\mathrm{Et} \\
\mathrm{Pr} \\
n \text {-Bu }\end{array}$ & $\begin{array}{l}\mathrm{Ph} \\
p \text {-Tol } \\
p \text {-Tol } \\
\mathrm{Ph} \\
\mathrm{Ph}\end{array}$ & $\begin{array}{l}\text { Toluene } \\
, \\
, \\
, \\
,\end{array}$ & $\begin{array}{l}92 \\
90 \\
91 \\
90 \\
94\end{array}$ & $\begin{array}{l}{[64]} \\
{[64]} \\
{[64]} \\
{[64]} \\
{[64]}\end{array}$ \\
\hline $\mathrm{RSnCl}_{3}+3 \mathrm{HR}^{\prime}$ & $n$-Bu & $\mathrm{SPM}^{\mathrm{b}}$ & $\mathrm{EtOH}, \mathrm{KOH}$ & 85 & [67] \\
\hline
\end{tabular}

${ }^{\mathrm{a}}$ In all cases $\mathrm{X}=\mathrm{Cl}$ if not stated otherwise.

${ }^{\mathrm{b}} \mathrm{SPM}$, monoanion of 2-mercaptopyrimidine.

Table 4

Synthesis of triorganotin halides $\mathrm{R}_{3} \mathrm{SnX}^{\mathrm{a}}$

\begin{tabular}{|c|c|c|c|c|}
\hline Method & $\mathrm{R}$ & Conditions & Yield & References \\
\hline $3 \mathrm{R}_{4} \mathrm{Sn}+\mathrm{SnX}_{4}$ & $\begin{array}{l}\mathrm{Me} \\
\mathrm{Et}, \mathrm{X}=\mathrm{Cl}, \mathrm{Br} \\
n-\mathrm{Pr} \\
n-\mathrm{Bu} \\
\mathrm{Et}, \mathrm{Ph} \\
\mathrm{Ph} \\
\mathrm{Me}, \mathrm{X}=\mathrm{Br}\end{array}$ & $\mathrm{AlCl}_{3}$ & $\begin{array}{l}93-99 \\
86-91 \\
88 \\
95 \\
87-89 \\
72-87 \\
89\end{array}$ & $\begin{array}{l}{[37,81]} \\
{[84]} \\
{[33]} \\
{[83]} \\
{[79]} \\
{[79-81]} \\
{[29]}\end{array}$ \\
\hline $\mathrm{R}_{4} \mathrm{Sn}+\mathrm{GeCl}_{4}$ & $\begin{array}{l}\mathrm{Et}, n-\mathrm{Bu} \\
n \text {-Bu }\end{array}$ & & $\begin{array}{l}>99 \\
81\end{array}$ & $\begin{array}{l}{[86]} \\
{[85]}\end{array}$ \\
\hline $\mathrm{R}_{4} \mathrm{Sn}+\mathrm{Co}(\mathrm{TPP}) \mathrm{Cl}$ & Et, $n$-Bu & $\mathrm{CHCl}_{3} / \mathrm{MeCN}$ & $>99$ & [91] \\
\hline $\mathrm{R}_{4} \mathrm{Sn}+\mathrm{X}_{2}$ & $\begin{array}{l}\mathrm{Ph}, \mathrm{X}=\mathrm{Br} \\
\mathrm{Ph}, \mathrm{X}=\mathrm{I}\end{array}$ & $\begin{array}{l}\text { Pyridine } \\
\mathrm{CCl}_{4}\end{array}$ & $\begin{array}{l}95 \\
75\end{array}$ & $\begin{array}{l}{[87]} \\
{[88]}\end{array}$ \\
\hline $\mathrm{R}_{4} \mathrm{Sn}+\mathrm{SnX} \mathrm{X}_{2}$ & $\begin{array}{l}\text { Et } \\
\text { Et, } \mathrm{X}=\mathrm{I}\end{array}$ & & $\begin{array}{l}78 \\
71\end{array}$ & $\begin{array}{l}{[68]} \\
{[68]}\end{array}$ \\
\hline $\mathrm{R}_{2} \mathrm{SnR}_{2}^{\prime}+\mathrm{BR}_{2} \rightarrow \mathrm{R}_{2} \mathrm{SnR}^{\prime} \mathrm{Br}$ & $\mathrm{R}=\mathrm{Ph} ; \mathrm{R}^{\prime}=n-\mathrm{Bu}, n-\mathrm{Hex}$, allyl, vinyl & $\mathrm{CCl}_{4}$ & $91-99$ & [71] \\
\hline $\mathrm{R}_{2} \mathrm{SnCl}_{2}+2 \mathrm{Sn}$ & $n-\mathrm{Bu}$ & $\mathrm{BuCl}$, pyridine & 74 & [63] \\
\hline $\mathrm{SnX} X_{4}+\mathrm{R}_{3} \mathrm{Al} / \mathrm{R}_{3} \mathrm{Al}_{2} \mathrm{Cl}_{3}$ & $\begin{array}{l}\text { Et } \\
\text { Et, } X=I \\
\text { Et, } X=I \\
\text { Et, } X=B r\end{array}$ & $\begin{array}{l}\mathrm{Et}_{2} \mathrm{O} \\
\mathrm{Et}_{2} \mathrm{O} \\
\mathrm{Et}_{2} \mathrm{O}\end{array}$ & $\begin{array}{l}93 \\
83 \\
87 \\
82\end{array}$ & $\begin{array}{l}{[54,55]} \\
{[54 \mathrm{~b}]} \\
{[55]} \\
{[55]}\end{array}$ \\
\hline $\mathrm{SnX}_{4}+3 \mathrm{RCu}$ & $\mathrm{Ph}$ & $\mathrm{Et}_{2} \mathrm{O}$ & 92 & [92] \\
\hline $2 \mathrm{Sn}+3 \mathrm{RCl}$ & $\mathrm{Bz}$ & $\mathrm{H}_{2} \mathrm{O}$ & 85 & {$[93,94]$} \\
\hline
\end{tabular}

${ }^{\mathrm{a}} \mathrm{In}$ all cases $\mathrm{X}=\mathrm{Cl}$ if not stated otherwise. 
Table 5

Synthesis of diorganotin dihalides $\mathrm{R}_{2} \mathrm{SnX}_{2}{ }^{\mathrm{a}}$

\begin{tabular}{|c|c|c|c|c|}
\hline Method & $\mathrm{R}$ & Conditions & Yield & References \\
\hline \multirow[t]{10}{*}{$\mathrm{R}_{4} \mathrm{Sn}+\mathrm{SnCl}_{4}$} & $\mathrm{Me}$ & & $85-91$ & {$[37,98]$} \\
\hline & $\mathrm{Me}, \mathrm{Et}, n-\mathrm{Pr} \mathrm{X}=\mathrm{Br}$ & & $85-99$ & {$[84]$} \\
\hline & $n-\mathrm{Bu}$ & & 95 & [46] \\
\hline & $n$-Hex & & 88 & [47] \\
\hline & $n$-Oct & & 84 & {$[47]$} \\
\hline & $\mathrm{Ph}$ & & $80-90$ & {$[49,50,96,97]$} \\
\hline & Vinyl & & 70 & {$[72]$} \\
\hline & Allyl & & 99 & {$[39,40]$} \\
\hline & $n-\mathrm{Bu}$ & $\mathrm{SnF}_{2}$ & 90 & [99] \\
\hline & $\mathrm{Ph}$ & $\mathrm{SnF}_{2}$ & 93 & [99] \\
\hline $\mathrm{R}_{4} \mathrm{Sn}+\mathrm{SbCl}_{5}$ & $\mathrm{Me}$ & $\mathrm{CH}_{2} \mathrm{Cl}_{2}$ & $>95$ & {$[100]$} \\
\hline $\mathrm{R}_{4} \mathrm{Sn}+2 \mathrm{SOCl}_{2}$ & $\mathrm{Me}, \mathrm{Et}, n-\mathrm{Pr}, \mathrm{Bz}$ & & $90-98$ & {$[105]$} \\
\hline $\mathrm{SnCl}_{4}+2 \mathrm{RLi}$ & Mes & $\mathrm{THF}$ & 21 & {$[103]$} \\
\hline $3 \mathrm{SnCl}_{4}+2 \mathrm{R}_{3} \mathrm{Al}_{2} \mathrm{Cl}_{3}$ & Et & $\mathrm{NaCl}$ & 93 & {$[60]$} \\
\hline $3 \mathrm{SnCl}_{4}+2 \mathrm{R}_{3} \mathrm{Al}$ & Et & $\mathrm{Et}_{3} \mathrm{~N}, \mathrm{Et}_{2} \mathrm{O}$ & $88-92$ & {$[54,55]$} \\
\hline $\mathrm{SnCl}_{4}+\mathrm{AlR}_{2} \mathrm{Cl}$ & $n-\mathrm{Bu}$ & & 95 & {$[54]$} \\
\hline $\mathrm{SnCl}_{4}+2[\mathrm{CuR}]_{5}($ toluene $)$ & Mes & Toluene & 97 & {$[102]$} \\
\hline $\mathrm{SnCl}_{2}+\mathrm{RCl}$ & $\mathrm{Me}$ & HMPT/NaI (cat) & 89-94 & {$[111,112]$} \\
\hline $\mathrm{SnX}_{2}+\mathrm{R}_{2} \mathrm{Hg}$ & $p-\mathrm{ClC}_{6} \mathrm{H}_{4} ; \mathrm{X}=\mathrm{Br}, \mathrm{I}$ & $\mathrm{EtOH}$ & $92-99$ & {$[115]$} \\
\hline \multirow[t]{7}{*}{$\mathrm{Sn}+2 \mathrm{RX}$} & $\mathrm{Me}$ & Mg, BuI, n-butanol & 92 & {$[108]$} \\
\hline & $n-\mathrm{Bu}$ & Dicyclohexyl-18-crown-6, DMF & $>99$ & {$[114]$} \\
\hline & $n$-Oct & Dibenzo-18-crown-6, DMF & 95 & {$[114]$} \\
\hline & Benzyl & Toluene & 81 & [94] \\
\hline & $n-\mathrm{Bu}, \mathrm{X}=\mathrm{I}$ & $\mathrm{Mg}, n$-butanol & 95 & [108] \\
\hline & $n-\mathrm{Bu}, \mathrm{X}=\mathrm{I}$ & $\mathrm{Mg}, \mathrm{Zn}, n$-butanol & 95 & [109] \\
\hline & Allyl, $\mathrm{X}=\mathrm{Br}$ & $\mathrm{HgCl}_{2}, \mathrm{Et}_{3} \mathrm{~N}$, toluene & 84 & {$[110]$} \\
\hline
\end{tabular}

${ }^{\mathrm{a}}$ In all cases $\mathrm{X}=\mathrm{Cl}$ if not stated otherwise.

The acute toxicity of an organotin depends on the number of organic groups bound to tin. In general, the maximum toxicological effect is found for the trisubstituted compounds $\mathrm{R}_{3} \mathrm{SnX}$. The nature of the $\mathrm{X}$ group has almost no effect whereas the chain length of alkyl groups has a considerable impact on toxicity. Methyltins are highly toxic while octyltins are essentially non-toxic, allowing their application as stabilizers in PVC for food packaging materials [19].

The today's worldwide production of organotin chemicals is about 50 kilotons annually [20]. The commercial production process of organotins starts with the conversion of metallic tin into $\mathrm{SnCl}_{4}$ by a reaction with chlorine gas [21]. Next, $\mathrm{SnCl}_{4}$ is converted into $\mathrm{R}_{4} \mathrm{Sn}$ by alkylation with $\mathrm{R}_{3} \mathrm{Al}$ or $\mathrm{RMgX}(\mathrm{R}=$ alkyl group; $\mathrm{X}=\mathrm{Cl}, \mathrm{Br}$ ) [17]. Finally, $\mathrm{R}_{4} \mathrm{Sn}$ serves as starting material for the synthesis of other organotin halides that can be generated through redistribution with $\mathrm{SnCl}_{4}$ [16]. In a final step, the remaining chloride anion(s) can then be substituted by the desired anion(s) (e.g., oxide, hydroxide, thioglycolate, carboxylate, triazolide, etc.).

The selective synthesis of the desired organotin compound has become more relevant because of envi- ronmental issues related to toxicity of some triorganotins and the more general demand for selective chemical processes (so-called green chemistry). During the last five decades, methods have been developed for the synthesis of organotin halides. These methods, which are often not selective enough to fulfil today's requirements and result in mixtures of different organotin products, have been discussed in earlier reviews [22-24] and monographs $[17,25,26]$. This review will focus on methods which give selective formation of the desired mono-, di-, tri or tetra-organotin halide.

Tables at the end of every section give a summary of available methods for the selective preparation of symmetric tetraorganotins (Table 2), mixed tetraorganotins (Table 3), triorganotin halides (Table 4), diorganotin dihalides (Table 5) and monoorganotin trihalides (Table 6).

\section{Symmetric tetraorganotins $\mathbf{R}_{4} \mathrm{Sn}$}

The most widely used route for the synthesis of tetraorganotin compounds, is the reaction of an appropriate Grignard reagent $\mathrm{RMgX}(\mathrm{R}=$ organic group; 
Table 6

Synthesis of monoorganotin trihalides $\mathrm{RSnX}_{3}{ }^{\mathrm{a}}$

\begin{tabular}{|c|c|c|c|c|}
\hline Method & $\mathrm{R}$ & Conditions & Yield & References \\
\hline $\mathrm{R}_{4} \mathrm{Sn}+3 \mathrm{SnCl}_{4}$ & $\begin{array}{l}\text { Et } \\
\text { Vinyl } \\
\mathrm{Ph}\end{array}$ & & $\begin{array}{l}94 \\
77 \\
78\end{array}$ & $\begin{array}{l}{[116]} \\
{[72]} \\
{[117]}\end{array}$ \\
\hline $\mathrm{R}_{2} \mathrm{SnCl}_{2}+\mathrm{SnCl}_{4}$ & $\begin{array}{l}\mathrm{Me} \\
\mathrm{Me} \\
\mathrm{Et} \\
\mathrm{Ph} \\
p-\mathrm{ClC}_{6} \mathrm{H}_{4} \\
n-\mathrm{BuOCOCH}_{2} \mathrm{CH}_{2} \\
\mathrm{MeOCOCH}{ }_{2} \mathrm{CH}_{2} \\
\mathrm{Me}, n-\mathrm{Bu}, n-\mathrm{Hex}\end{array}$ & $\begin{array}{l}\mathrm{NR}_{4} \mathrm{Cl}, \mathrm{MeCl} \\
\mathrm{DMSO} \\
\mathrm{POCl}_{3} / \mathrm{P}_{2} \mathrm{O}_{5}\end{array}$ & $\begin{array}{l}98 \\
>90 \\
92 \\
80 \\
>99 \\
>99 \\
>99 \\
67-87\end{array}$ & $\begin{array}{l}{[120]} \\
{[119]} \\
{[116]} \\
{[96]} \\
{[115]} \\
{[118]} \\
{[118]} \\
{[121]}\end{array}$ \\
\hline $\mathrm{R}_{2} \mathrm{SnCl}_{2}+\mathrm{SbCl}_{5}$ & $\mathrm{Me}$ & $\mathrm{CH}_{2} \mathrm{Cl}_{2}$ & $>95$ & {$[100]$} \\
\hline $\mathrm{SnCl}_{4}+\mathrm{R}_{4} \mathrm{Ge}$ & $\begin{array}{l}\mathrm{Et}, n-\mathrm{Bu} \\
n-\mathrm{Bu}\end{array}$ & & $\begin{array}{l}>99 \\
94\end{array}$ & $\begin{array}{l}{[86]} \\
{[85]}\end{array}$ \\
\hline $2 \mathrm{SnCl}_{4}+\mathrm{R}_{2} \mathrm{Al}(\mathrm{O} i-\mathrm{Pr})$ & $n$-Oct & $n-\mathrm{Bu}_{2} \mathrm{O}$ & 97 & [122] \\
\hline $3 \mathrm{SnCl}_{4}+\mathrm{R}_{3} \mathrm{Al}(n-\mathrm{Bu})_{2} \mathrm{O}$ & $n$-Oct & $n-\mathrm{Bu}_{2} \mathrm{O}$ & 90 & [123] \\
\hline $\mathrm{SnCl}_{4}+[\mathrm{CuR}]_{5}($ toluene $)$ & Mes & Toluene & 97 & [102] \\
\hline $\mathrm{SnCl}_{4}+$ alkene $+\mathrm{CpZr}(\mathrm{H}) \mathrm{Cl}$ & $n$-Oct & Benzene & 81 & [136] \\
\hline $\mathrm{SnCl}_{2}+\mathrm{RX}$ & $\begin{array}{l}\mathrm{Me} \\
n \text {-Bu, } n \text {-Oct; } \mathrm{X}=\mathrm{Br}\end{array}$ & $\begin{array}{l}\mathrm{I}_{2}, \mathrm{Mg}, \mathrm{THF} \text {, toluene } \\
\mathrm{R}_{3} \mathrm{Sb}\end{array}$ & $\begin{array}{l}95 \\
84-96\end{array}$ & $\begin{array}{l}{[126]} \\
{[124]}\end{array}$ \\
\hline $\mathrm{SnCl}_{2}+\mathrm{HCl}+\mathrm{CH}_{2}=\mathrm{CHCOOR}$ & $\mathrm{H}, \mathrm{Me}, n-\mathrm{Bu}, \mathrm{Ph}$ & $\left(\mathrm{MeOCH}_{2}\right)_{2}$ & $89-98$ & {$[128,129]$} \\
\hline $\mathrm{SnCl}_{2}+\mathrm{HCl}+\mathrm{ROC}(\mathrm{O}) \mathrm{CH}=\mathrm{CHCH}_{2} \mathrm{C}(\mathrm{O}) \mathrm{OR}$ & $\mathrm{Me}, \mathrm{Et}, n-\mathrm{Bu}$ & $\left(\mathrm{MeOCH}_{2}\right)_{2}$ & $98-99$ & [127] \\
\hline
\end{tabular}

${ }^{\mathrm{a}}$ In all cases $\mathrm{X}=\mathrm{Cl}$ if not stated otherwise.

$\mathrm{X}=\mathrm{Cl}, \mathrm{Br}$, I) with a tin(IV) halide, usually $\mathrm{SnCl}_{4}$ (Eq. (1)) $[24,27-37]$.

$$
\begin{aligned}
& 4 \mathrm{RM} / 2 \mathrm{R}_{2} \mathrm{M}^{\prime}+\mathrm{SnX}_{4} \\
& \left.\underset{\substack{\mathrm{M}=\mathrm{MgX} \\
\mathrm{X}=\mathrm{Cl}, \mathrm{Br}, \mathrm{I}}}{\longrightarrow} \mathrm{X}^{\prime}=\mathrm{Cl}, \mathrm{Br}, \mathrm{I}\right), \mathrm{Na}, \mathrm{Li} ; \mathrm{M}^{\prime}=\mathrm{Zn} \\
& \longrightarrow
\end{aligned}
$$

This reaction is usually carried out in coordinating solvents like diethyl ether $\left(\mathrm{Et}_{2} \mathrm{O}\right)$, dibutyl ether $\left(\mathrm{Bu}_{2} \mathrm{O}\right)$ or tetrahydrofuran (THF). In order to promote full substitution of $\mathrm{SnCl}_{4}$, an excess of Grignard reagent is used. With this method, tetravinyl [38], tetraallyl [39-41], tetraalkyl [30-36] and tetraaryl tins [42-45] can be obtained in yields higher than $90 \%$. Since most Grignard reagents are commercially available or easy to prepare, this method is commonly used for the preparation of tetraorganotins.

For the tetraalkyltins with alkyl groups longer than $\mathrm{R}=\mathrm{Bu}$, a substantial excess of Grignard reagent is often required to obtain full conversion. In that case, a Wurtz-type reaction of $\mathrm{SnCl}_{4}$ with an in situ prepared organosodium can be more efficient (Eq. (1), $\mathrm{M}=\mathrm{Na}$ ) [46-50]. In this way, tetrahexyltin and even tetraoctyltin can be prepared in yields up to $80 \%$. Disadvantages of the latter approach are the difficulty to control the reaction conditions and to prevent the formation of distannanes $\left(\mathrm{R}_{3} \mathrm{SnSnR}_{3}\right)$.
Also organolithiums can be used. This reagent is suitable for the synthesis of tetraaryltins [24] and $\mathrm{Me}_{4} \mathrm{Sn}$ [51]. Also in this case, yields are generally rather low due to the formation of significant amounts of distannanes. For the preparation of tetraaryltins, diarylzinc reagents have proven to be more useful since in these transaryllation reactions no distannanes are formed (Eq. (1), $\mathrm{M}^{\prime}=\mathrm{Zn}$ ). For example, diphenylzinc gives $\mathrm{Ph}_{4} \mathrm{Sn}$ in yields higher than $90 \%$ and in high purity [52].

The organometallic reagents discussed so far have the disadvantage that they either have to be applied in excess or result in substantial distannane formation. Like the diarylzinc compounds, triorganoaluminium reagents $\left(\mathrm{R}_{3} \mathrm{Al}\right)$ do not give distannanes and under some conditions, even an excess of $\mathrm{R}_{3} \mathrm{Al}$ is not necessary [55,56]. Nowadays, $\mathrm{R}_{3} \mathrm{Al}$ is generally used as alkylating agent for the industrial preparation of tetraalkyltins (Eq. (2))

$4 \mathrm{R}_{3} \mathrm{Al}+3 \mathrm{SnX}_{4} \underset{(\mathrm{X}=\mathrm{Cl}, \mathrm{Br})}{\longrightarrow} 3 \mathrm{R}_{4} \mathrm{Sn}+4 \mathrm{AlX}_{3}$

When the reaction is carried out with stoichiometric amounts of $\mathrm{SnCl}_{4}$ and $\mathrm{R}_{3} \mathrm{Al}, \mathrm{R}_{4} \mathrm{Sn}$ is obtained in less than $10 \%$ yield owing to the formation of stable $\mathrm{R}_{2} \mathrm{SnCl}_{2}\left(\mathrm{AlCl}_{3}\right)$ and $\mathrm{R}_{3} \mathrm{SnCl}\left(\mathrm{AlCl}_{3}\right)$ complexes. Consequently, an excess of $\mathrm{R}_{3} \mathrm{Al}$ is necessary to reach full alkylation of $\mathrm{SnCl}_{4}$. Upon addition of ethers $[55,57]$ or $\mathrm{NaCl} / \mathrm{KCl}$ [57-60], the $\mathrm{R}_{4-y} \mathrm{SnCl}_{y}\left(\mathrm{AlCl}_{3}\right)$ complexes are 
converted into the more stable complexes $\mathrm{AlCl}_{3}\left(\mathrm{R}_{2}^{\prime} \mathrm{O}\right)$ and $\mathrm{Na}\left[\mathrm{AlCl}_{4}\right] / \mathrm{K}\left[\mathrm{AlCl}_{4}\right]$, respectively, and the respective tetraalkyltins (Eqs. (3) and (4)). As a result, full alkylation is reached without an excess of $\mathrm{R}_{3} \mathrm{Al}$

$$
\begin{aligned}
& 4 \mathrm{R}_{3} \mathrm{Al}+3 \mathrm{SnCl}_{4}+4 \mathrm{R}_{2}^{\prime} \mathrm{O} \rightarrow 3 \mathrm{R}_{4} \mathrm{Sn}+4 \mathrm{AlCl}_{3}\left(\mathrm{R}_{2}^{\prime} \mathrm{O}\right) \\
& 4 \mathrm{R}_{3} \mathrm{Al}+3 \mathrm{SnCl}_{4}+4 \mathrm{NaCl} \rightarrow 3 \mathrm{R}_{4} \mathrm{Sn}+4 \mathrm{Na}\left[\mathrm{AlCl}_{4}\right]
\end{aligned}
$$

A modification of this method is the procedure described by Sundermeyer and Verbeek $[61,62]$. He prepared the alkylating agent $\mathrm{Na}\left[\mathrm{AlMeCl} \mathrm{M}_{3}\right]$ in one step by electrolysis of a $\mathrm{NaCl} / \mathrm{AlCl}_{3}$ melt followed by a reaction with $\mathrm{MeCl}$. Next, the $\mathrm{Na}\left[\mathrm{AlMeCl}_{3}\right]$ formed reacts quantitatively with $\mathrm{SnCl}_{4}$ to afford $\mathrm{SnMe}_{4}$ in $95 \%$ yield.

The methods described so far, all make use of $\mathrm{SnCl}_{4}$ as starting compound. But also organotin halides can be applied. For example, Sisido and Kozima [63] demonstrated that $n-\mathrm{Bu}_{2} \mathrm{SnCl}_{2}$ can be converted into a mixture of $n-\mathrm{Bu}_{4} \mathrm{Sn}$ and $n-\mathrm{Bu}_{3} \mathrm{SnCl}$ by reaction with a metal (Fe, $\mathrm{Zn}, \mathrm{Al}, \mathrm{Mg}, \mathrm{Na}$ ) in the presence of an organic base as solvent/catalyst. When the reaction was carried out using a zinc-triethylamine mixture, $n$ - $\mathrm{Bu}_{4} \mathrm{Sn}$ was obtained in $58 \%$ yield.

$n-\mathrm{Bu}_{2} \mathrm{SnCl}_{2} \stackrel{\mathrm{Zn}, \mathrm{Et}_{3} \mathrm{~N}}{\longrightarrow} n-\mathrm{Bu}_{4} \mathrm{Sn}$

More recently, Sharutin et al. [64] prepared tetraphenyltin by reacting diphenyltin dichloride with pentaphenylantimony (Eq. (6)) affording the desired product in a $95 \%$ yield

$\mathrm{Ph}_{2} \mathrm{SnCl}_{2}+2 \mathrm{Ph}_{5} \mathrm{Sb} \rightarrow \mathrm{Ph}_{4} \mathrm{Sn}+2 \mathrm{Ph}_{4} \mathrm{SbCl}$

This method was also applicable for the synthesis of unsymmetric tetraorganotins (see Section 3). However, both procedures are less relevant for the synthesis of tetraorganotins, because the tetraorganotins themselves are generally used as starting materials, e.g., for the preparation of diorganotin dihalides.

\section{Mixed tetraorganotins $\mathbf{R}_{2} \mathbf{R}_{2}^{\prime} \mathrm{Sn}, \mathbf{R}_{\mathbf{3}} \mathbf{R}^{\prime} \mathrm{Sn}, \mathbf{R}_{\mathbf{2}} \mathbf{R}^{\prime} \mathbf{R}^{\prime \prime} \mathrm{Sn}$ and chiral $\mathbf{R R}^{\prime} \mathbf{R}^{\prime \prime} \mathbf{R}^{\prime \prime} \mathbf{S n}$}

Like symmetric tetraorganotins, mixed tetraorganotins are prepared by alkylation of a tin halide. In this case not a tin tetrahalide, but a di- or triorganotin halide is used. Alkylation of the organotin halide occurs by reaction with an excess of Grignard reagent $\mathrm{R}^{\prime} \mathrm{MgX}$ (Eqs. (7), (8); $\mathrm{R} \neq \mathrm{R}^{\prime}=$ organic group; $\mathrm{X}=\mathrm{Cl}$ ) [64-73]. In this way, mixed tetraorganotins of the type $R_{2} R_{2}^{\prime} S n$ and $\mathrm{R}_{3} \mathrm{R}^{\prime} \mathrm{Sn}$ can be obtained in high yields

$$
\begin{aligned}
& \mathrm{R}_{2} \mathrm{SnX}_{2}+2 \mathrm{R}^{\prime} \mathrm{MgX} \stackrel{\text { ether or THF }}{\longrightarrow} \mathrm{R}_{2} \mathrm{R}_{2}^{\prime} \mathrm{Sn}+2 \mathrm{MgX}_{2} \\
& \mathrm{R}_{3} \mathrm{SnX}+\mathrm{R}^{\prime} \mathrm{MgX} \stackrel{\text { ether or THF }}{\longrightarrow} \mathrm{R}_{3} \mathrm{R}^{\prime} \mathrm{Sn}+\mathrm{MgX}_{2}
\end{aligned}
$$

For the functionalization of organotin halides with aryl groups, pentaarylantimony has proven to be an useful reagent [64]. An advantage of this reagent over a Grignard reagent is the high reactivity of pentaarylantimony, which makes an excess of reagent not necessary.

Except for organtins with bulky organic groups such as neophyl [74], successful stepwise addition of two different groups to $\mathrm{R}_{2} \mathrm{SnCl}_{2}$ to yield $\mathrm{R}_{2} \mathrm{R}^{\prime} \mathrm{R}^{\prime \prime} \mathrm{Sn}$ with the successive use of two different Grignard reagents in a row, is almost impossible (Eq. (9); $\mathrm{X}=\mathrm{Cl}, \mathrm{Br}$ )

$\mathrm{R}_{2} \mathrm{SnX}_{2}+\stackrel{\mathrm{R}^{\prime} \mathrm{MgX}}{\longrightarrow} \mathrm{R}_{2} \mathrm{R}^{\prime} \mathrm{Sn} \stackrel{\mathrm{R}^{\prime \prime} \mathrm{MgX}}{\longrightarrow}+\mathrm{R}_{2} \mathrm{R}^{\prime} \mathrm{R}^{\prime \prime} \mathrm{Sn}$

Therefore the following reaction sequence has been developed for the selective preparation of these types of compounds (Scheme 1) [69-71].

At first, the dialkyltin dihalide $\left(\mathrm{R}_{2} \mathrm{SnX} \mathrm{X}_{2}\right)$ is fully converted into the mixed tetraorganotin $\mathrm{R}_{2} \mathrm{R}_{2}^{\prime} \mathrm{Sn}$ by a reaction with two equivalents of $\mathrm{R}^{\prime} \mathrm{MgX}$. Addition of one equivalent of dihalogen results in the selective cleavage of one of the organic groups with formation of $R_{2} R^{\prime} S n X$. Reaction with the second Grignard reagent then affords the desired mixed $R_{2} R^{\prime} R^{\prime \prime} S n$ compound. Sharutin et al. [64] demonstrated that this procedure can be shortened for $\mathrm{R}^{\prime}=$ aryl by preparing $\mathrm{R}_{2} \mathrm{R}^{\prime} \mathrm{SnX}$ in one step from the reaction of $\mathrm{R}_{2} \mathrm{SnX}_{2}$ with one equivalent of $\mathrm{R}_{5}^{\prime} \mathrm{Sb}$. In this case, selective aryl transfer from antimony to tin occurs and $R_{2} R^{\prime} S n X$ is formed exclusively.

A further extension of this approach has opened up the way to chiral tetraorganotins $R^{\prime} R^{\prime \prime} R^{\prime \prime \prime} S n$ that have found limited practical application compared to their carbon-based counterparts. Addition of racemic stannane $\mathrm{NpArMeSnH}$ to (-)-menthyl acrylate followed by separation of the diastereomeric adducts afforded one of the pure diastereomers [75] (Scheme 2).

Enantioenriched tetraorganotins have also been prepared through enantioselective substitution of the alkoxide group by a Grignard reagent in diastereomeric triorganotin alkoxides $\mathrm{R}^{1} \mathrm{R}^{2} \mathrm{R}^{3} \mathrm{SnOR}^{*}\left(\mathrm{R}^{*}=\right.$ chinconyl) [76]. Chiral tetraorganotins can undergo facile racemization, especially in polar solvent and/or higher concentration through involvement of pentacoordinate tin intermediates.

$$
R_{2} S n X \stackrel{2 R^{\prime} M g X}{\longrightarrow} R_{2} S_{2} R_{2}^{\prime} \stackrel{X_{2}}{\longrightarrow} R_{2} R^{\prime} S n X \stackrel{R^{\prime \prime} M g X}{\longrightarrow} R_{2} R^{\prime} R^{\prime \prime} S n
$$

Scheme 1. Reaction sequence for the synthesis of mixed tetraorganotins from diorganotin dihalides with $\mathrm{R}=$ alkyl, $\mathrm{R}^{\prime}=$ aryl, acyl, vinyl and $\mathrm{R}^{\prime \prime}=$ alkyl, aryl, acyl, vinyl; $\mathrm{X}=\mathrm{Cl}, \mathrm{Br}, \mathrm{I}$.

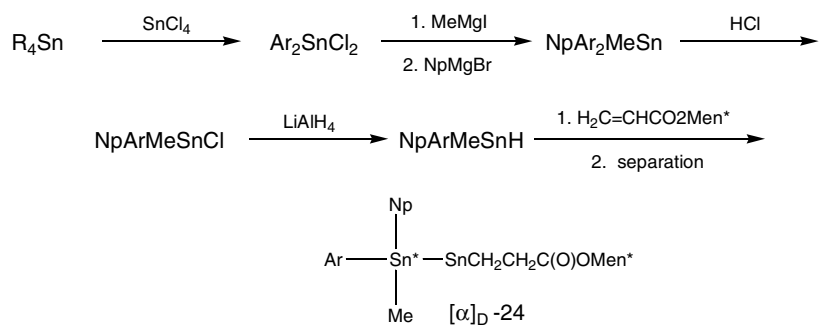

Scheme 2. Np, 1-naphtyl; Men*, (-)-menthyl, $\mathrm{Ar}=p-\mathrm{MeOC}_{6} \mathrm{H}_{4}^{-}$. 


\section{Triorganotin halides $\mathbf{R}_{3} \mathrm{SnX}$}

The usual way to prepare triorganotin halides is the Kocheshkov redistribution reaction of three equivalents of tetraorganotin with one equivalent of tin tetrahalide (Eq. (10); $\mathrm{M}=\mathrm{Sn} ; \mathrm{X}=\mathrm{Cl}, \mathrm{Br}$ ) $[24,77]$

$3 \mathrm{R}_{4} \mathrm{Sn}+\mathrm{MX}_{4} \rightarrow 4 \mathrm{R}_{3} \mathrm{SnX}$

With this method triallyl $[28,39,40]$, triphenyl [78-81] and trialkyltin halides $[29,33,37,82-84]$ can be prepared in good yields. The reaction is commonly carried out without solvent at temperatures between 100 and 200 ${ }^{\circ} \mathrm{C}$. Banks [79] claimed that upon addition of $\mathrm{AlCl}_{3}$, this conversion required shorter reaction times and lower reaction temperatures. This was indeed found to be the case for ethyltins, but does not apply for other organotins.

This redistribution reaction, can also be carried out using another group IV metal halide like $\mathrm{GeCl}_{4}$ (Eq. (10), $\mathrm{M}=\mathrm{Ge}, \mathrm{X}=\mathrm{Cl}$ ) instead of $\mathrm{SnCl}_{4}$. In a fast reaction $(1 \mathrm{~h})$ an equimolar mixture of $\mathrm{R}_{3} \mathrm{SnCl}$ and $\mathrm{RGeCl}_{3}$, respectively, is obtained $[85,86]$. Using this reaction, $\mathrm{Bu}_{3} \mathrm{SnCl}$ and $\mathrm{Et}_{3} \mathrm{SnCl}$ can be prepared in quantitative yield. The side-product $\mathrm{RGeCl}_{3}$ can be removed by fractional distillation of the reaction mixture. Formation of other organotin halides is not observed, which makes this method highly selective for $\mathrm{R}_{3} \mathrm{SnCl}$.

In addition to the use of a tin(IV) halide in the Kocheshkov redistribution reaction, also a tin(II) halide can be used (Eq. (11); $\mathrm{X}=\mathrm{Cl}, \mathrm{Br}, \mathrm{I}$ ) [68]

$2 \mathrm{R}_{4} \mathrm{Sn}+\mathrm{SnX}_{2} \rightarrow 2 \mathrm{R}_{3} \mathrm{SnX}+\mathrm{Sn}+\mathrm{R}-\mathrm{R}$

The starting tetraorganotin reacts with the tin(II) halide to give $\mathrm{R}_{3} \mathrm{SnX}$, metallic tin and the $\mathrm{C}-\mathrm{C}$ coupled product $\mathrm{R}-\mathrm{R}$. This reaction was found to be highly selective for the formation of triethyltin halides. For the different halides, $\mathrm{Cl}, \mathrm{Br}$ and $\mathrm{I}$, no formation of diethyltin dihalide was observed at all.

The selective cleavage of one tin-carbon bond in $\mathrm{R}_{4} \mathrm{Sn}$ can also be achieved by the use dihalogens like $\mathrm{Cl}_{2}, \mathrm{Br}_{2}$ and $\mathrm{I}_{2}$. They react with $\mathrm{R}_{4} \mathrm{Sn}$ by cleavage of tincarbon bonds under formation of an organic halide and an organotin halide [24]. When this reaction is performed in a $1: 1$ molar ratio at $-50^{\circ} \mathrm{C}$, selective cleavage of one of the tin-carbon bonds is possible to give $\mathrm{R}_{3} \mathrm{SnX}$ and the organic halide RX (Eq. (12), $\mathrm{X}=\mathrm{Cl}, \mathrm{Br}, \mathrm{I}$ ) $[71,87,88]$

$\mathrm{R}_{4} \mathrm{Sn}+\mathrm{X}_{2} \underset{-50^{\circ} \mathrm{C}}{\longrightarrow} \mathrm{R}_{3} \mathrm{SnX}+\mathrm{RX}$

Generally, this reaction is performed with $\mathrm{Br}_{2}$ as it reacts more promptly than $\mathrm{I}_{2}$ and is more easy to handle than $\mathrm{Cl}_{2}$. If the triorganotin chloride or iodide are desired, a procedure can be used which makes use of the triorganotin bromide (Scheme 3) [87].

Hydrolysis of the tin bromide under basic conditions results in the formation of the trialkyltin oxide in 90
$\mathrm{R}_{3} \mathrm{SnBr} \stackrel{30 \% \mathrm{KOH} \text { (aq.) }}{\longrightarrow} 1 / 2\left[\mathrm{R}_{3} \mathrm{Sn}\right]_{2} \mathrm{O} \stackrel{1 \text { eq. } \mathrm{HX}}{\longrightarrow} \mathrm{R}_{3} \mathrm{SnX}$

Scheme 3. Conversion of $\mathrm{R}_{3} \mathrm{SnBr}$ into $\mathrm{R}_{3} \mathrm{SnX}(\mathrm{X}=\mathrm{Cl}, \mathrm{I})$.

95\% yield. This oxide then provides a convenient starting material for the reaction with HX to give the corresponding triorganotin halide with high selectivity.

In addition to a dihalogen, $\mathrm{HX}(\mathrm{X}=\mathrm{Cl}, \mathrm{Br}, \mathrm{I})$ can be used to cleave tin-carbon bonds under formation of an alkane as side-product $[89,90]$ However, this reaction is somewhat more difficult to control than the reaction with $\mathrm{X}_{2}$ as it makes use of gaseous HX, which is more difficult to dose. Furthermore, dry HX has to be used. Otherwise the formation of undesired tin hydroxides can occur [17].

Trialkyltin chlorides are formed as side-products in the reaction of equimolar amounts of tetraorganotins with $\mathrm{Co}$ (TPP) $\mathrm{Cl}$ (TPP = dianion of tetraphenylporhyrin). In this reaction, $\mathrm{R}_{4} \mathrm{Sn}$ is used as a mild alkylating agent (Eq. (13)) [91]

$$
\mathrm{R}_{4} \mathrm{Sn}+\mathrm{Co}(\mathrm{TPP}) \mathrm{Cl} \underset{\mathrm{CH}_{3} \mathrm{Cl} / \mathrm{CH}_{3} \mathrm{CN}}{\longrightarrow} \mathrm{R}_{3} \mathrm{SnCl}+\mathrm{Co}(\mathrm{TPP}) \mathrm{R}
$$

The reaction is facile when the least hindered tetraalkyltin, i.e., $\mathrm{Me}_{4} \mathrm{Sn}$ is used. In that case, the reaction goes to completion at room temperature within $10 \mathrm{~min}$. When a more sterically hindered tetraalkyltin like $n$ $\mathrm{Bu}_{4} \mathrm{Sn}$ is used, the reaction time increases to $180 \mathrm{~min}$. Unfortunately, it was not reported whether the cobalt complex could be separated from the trialkyltin chloride.

In addition to selective carbon-tin bond cleavage, selective carbon-tin bond formation is also possible. Addition of one equivalent of an alkylating aluminum reagent $\left(\mathrm{R}_{3} \mathrm{Al}, \mathrm{R}_{3} \mathrm{Al}_{2} \mathrm{Cl}_{3}\right)$ to one equivalent of $\mathrm{SnCl}_{4}$ in the presence of triethylamine or diethyl ether results in the selective formation of $\mathrm{R}_{3} \mathrm{SnCl}$ in yields higher than 90\% (Eq. (14); $\mathrm{X}=\mathrm{Cl}$, I) [54,55]

$$
\begin{aligned}
& \mathrm{SnX}_{4}+\mathrm{R}_{3} \mathrm{Al} \text { or } \mathrm{R}_{3} \mathrm{Al}_{2} \mathrm{Cl}_{3} \\
& \underset{\mathrm{Et}_{2} \mathrm{O} / \mathrm{Et}_{3} \mathrm{~N}}{\longrightarrow} \mathrm{R}_{3} \mathrm{SnX}+\mathrm{AlX}_{3} \text { or } 2 \mathrm{AlX}_{3-n} \mathrm{Cl}_{n}
\end{aligned}
$$

With this method, only the preparation of $\mathrm{Et}_{3} \mathrm{SnCl}$ and $\mathrm{Et}_{3} \mathrm{SnI}$ was described. The scope of this reaction is not clear because no further examples were given in the patent application.

Triphenyltin chloride can be prepared by selective trisubstitution of tin tetrachloride with phenylcopper in diethyl ether (Eq. (15)) [92]. The phenylcopper reagent was prepared from the reaction of phenyllithium with cuprous bromide. After filtration of the reaction mixture, pure triphenyltin chloride is obtained in $92 \%$ yield

$\mathrm{SnCl}_{4} \underset{\mathrm{Et}_{2} \mathrm{O}, 0{ }^{\circ} \mathrm{C}}{\stackrel{\mathrm{PhCu}}{\longrightarrow}} \mathrm{Ph}_{3} \mathrm{SnCl}$ 


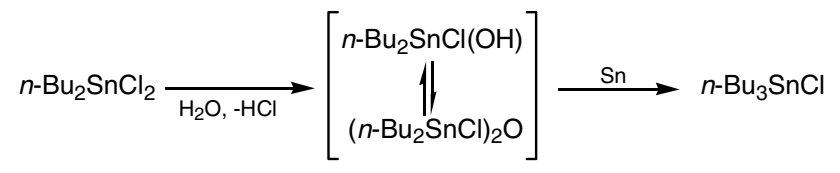

Scheme 4. Conversion of in situ formed bis-oxide into the triorganotin halide by reduction with metallic tin.

In addition to tin tetrahalides and tetraalkyltins, diorganotin dihalides can be used for the preparation of triorganotin halides. For example, $n-\mathrm{Bu}_{2} \mathrm{SnCl}_{2}$ can be converted by metallic tin powder into $n-\mathrm{Bu}_{3} \mathrm{SnCl}$ with high selectivity [63]. The reaction is carried out in water at high temperatures $\left(160{ }^{\circ} \mathrm{C}\right)$. In the absence of metallic tin, hydrolysis of $n-\mathrm{Bu}_{2} \mathrm{SnCl}_{2}$ occurs to give (n$\left.\mathrm{Bu}_{2} \mathrm{SnCl}\right)_{2} \mathrm{O}$. In the presence of both metallic tin and water, this oxide converts at high temperatures into $n$ $\mathrm{Bu}_{3} \mathrm{SnCl}$ in $45 \%$ yield. It was proposed that metallic tin acts as reducing agent in the conversion of the bis-oxide into $n-\mathrm{Bu}_{3} \mathrm{SnCl}$ (Scheme 4).

However, when the reaction medium was changed from water to butyl chloride and pyridine was added to the reaction mixture, full conversion of $n-\mathrm{Bu}_{2} \mathrm{SnCl}_{2}$ into $n-\mathrm{Bu}_{3} \mathrm{SnCl}$ was possible. The formation of $(n-$ $\left.\mathrm{Bu}_{2} \mathrm{SnCl}\right)_{2} \mathrm{O}$ as a side-product was not observed. Instead of $\mathrm{Sn}$, also other metals such as iron and zinc could be employed in this reaction, however, in these cases the yields of $n-\mathrm{Bu}_{3} \mathrm{SnCl}$ were always lower.

A final route for the preparation of triorganotin halides discussed in this section involves the direct reaction of benzyl chloride with metallic tin $[93,94]$. When this reaction is carried out in organic solvents such as toluene, dibenzyltin dichloride is formed. By changing the solvent to a more polar solvent like water, selective formation of tribenzyltin chloride is observed (Eq. (16)). Also ortho, meta and para substituted benzyl chlorides were used in this reaction. Yields of the substituted tribenzyltin chlorides were significant lower, however

$$
3 \mathrm{BzCl}+2 \underset{\mathrm{H}_{2} \mathrm{O}}{\rightarrow} \mathrm{Bz}_{3} \mathrm{SnCl}+\mathrm{SnCl}_{2}
$$

Sisido et al. [93] suggested that metallic tin reacts initially with benzyl chloride to give dibenzyltin dichloride which subsequently reacts in water in the presence of metallic tin to give tribenzyltin chloride.

Asymetrically substituted triorganotin halides $\mathrm{RR}^{\prime}$ $\mathrm{R}^{\prime \prime} \mathrm{SnX}$ are generally not configurationally stable enough to afford chiral complexes, unless a chelating $\mathrm{R}$ group such as ortho-(dimethylaminomethyl)phenyl with an intramolecularly-coordinating Lewis base is used [95].

\section{Diorganotin dihalides $\mathbf{R}_{2} \mathrm{SnX}_{2}$}

The most convenient way to prepare diorganotin dihalides is by a Kocheshkov redistribution reaction of
$\mathrm{R}_{4} \mathrm{Sn}$ with $\mathrm{SnX}_{4}$ in stoichiometric amounts carried out without solvent at a temperature of $150-200{ }^{\circ} \mathrm{C}$ (Eq. (17); $\mathrm{X}=\mathrm{Cl}, \mathrm{Br}$ )

$\mathrm{R}_{4} \mathrm{Sn}+\mathrm{SnX}_{4} \rightarrow 2 \mathrm{R}_{2} \mathrm{SnX}_{2}$

With this method, diallyltin- [28,39,40], diphenyltin[49,50,96,97], divinyltin- [72] and dialkyltin dihalides $[37,46,47,84,98]$ can be prepared in $80-90 \%$ yield. For $\mathrm{R}=$ allyl, vinyl, phenyl and alkyls up to propyl, this reaction goes to completion within a few hours. According to Buschhoff, $\mathrm{SnF}_{2}$ acts as a catalyst for redistribution reactions of organotin compounds with tin halides [99]. However, no indisputable proof was given for the catalytic activity of $\mathrm{SnF}_{2}$.

Other Lewis acids than $\mathrm{SnCl}_{4}$ can be employed in the Kocheshkov redistribution reaction with tetraorganotins. For example, $\mathrm{SbCl}_{5}$ and $\mathrm{BCl}_{3}$ are useful for the conversion of $\mathrm{Me}_{4} \mathrm{Sn}$ into $\mathrm{Me}_{2} \mathrm{SnCl}_{2}$ [100]. In the case of $\mathrm{BCl}_{3}$, an excess of this reagent can be used since the desired product $\mathrm{Me}_{2} \mathrm{SnCl}_{2}$ does not react any further with $\mathrm{BCl}_{3}$. However, organotins with rather weak $\mathrm{Sn}-\mathrm{C}$ bonds like $\mathrm{Ph}_{2} \mathrm{SnCl}_{2}$ cannot be prepared with these Lewis acids while all phenyl groups are easily transferred from tin(IV) to antimony or boron resulting in $\mathrm{SnCl}_{4}$ and $\mathrm{Ph}_{2} \mathrm{SbCl}_{3}$ or a mixture of $\mathrm{PhBCl}_{2}$ and $\mathrm{Ph}_{2} \mathrm{BCl}$, respectively.

Selective dialkylation of $\mathrm{SnCl}_{4}$ is possible with alkylaluminum reagents like $\mathrm{R}_{3} \mathrm{Al}$ [55], $\mathrm{R}_{2} \mathrm{AlCl}$ [54] (in the presence of $\mathrm{R}_{3} \mathrm{~N}, \mathrm{R}_{2} \mathrm{O}$ or $\mathrm{KCl}$ ) and $\mathrm{R}_{3} \mathrm{Al}_{2} \mathrm{Cl}_{3}$ [60]. Especially the latter reagent is very suitable for the synthesis of diethyltin dihalides in high yields. Moreover, with this reagent no addition of $\mathrm{R}_{3} \mathrm{~N}, \mathrm{R}_{2} \mathrm{O}$ or $\mathrm{KCl}$ is required. Ethylaluminium sesquihalides, $\mathrm{Et}_{3} \mathrm{Al}_{2} \mathrm{X}_{3}$ $(\mathrm{X}=\mathrm{Cl}, \mathrm{Br})$ are readily available and are prepared industrially by reacting metallic alumina with ethyl halide [101]. The use of $\mathrm{Et}_{3} \mathrm{Al}_{2} \mathrm{X}_{3}$ makes it possible to alkylate under milder conditions (e.g., temperature range 50-70 ${ }^{\circ} \mathrm{C}$ ) as compared with those required in the case of $\mathrm{R}_{3} \mathrm{Al}$ $\left(120-140{ }^{\circ} \mathrm{C}\right)$.

Also organo-copper and -lithium compounds can be used to synthesize diorganotin dihalides starting from $\mathrm{SnCl}_{4}$. However, this method is only suitable for a limited group of substituents. One example is the use of [CuMes $]_{5}$ (toluene), which is able to substitute $\mathrm{SnCl}_{4}$ in a selective way [102]. When two equivalents of this reagent are reacted with $\mathrm{SnCl}_{4}, \mathrm{Mes}_{2} \mathrm{SnCl}_{2}$ is obtained in $87 \%$ yield and $97 \%$ purity. In contrast to this selective arylation, the reaction of $\mathrm{MesLi}$ with $\mathrm{SnCl}_{4}$ was less successful and yielded $\mathrm{Mes}_{2} \mathrm{SnCl}_{2}$ in a low yield (21\%) [103].

Another possible route to diorganotin dichlorides involves the reaction of tetraorganotins with $\mathrm{HCl}$ $[90,104]$ or $\mathrm{SOCl}_{2}[105]$ resulting in the selective cleavage of two $\mathrm{Sn}-\mathrm{C}$ bonds (Eq. (18)).

$$
\begin{aligned}
& \mathrm{R}_{4} \mathrm{Sn}+2 \mathrm{HCl} \text { or } \mathrm{SOCl}_{2} \\
& \quad \rightarrow \mathrm{R}_{2} \mathrm{SnCl}_{2}+2 \mathrm{RH} \text { or } \mathrm{RSOCl}
\end{aligned}
$$


The order of reactivity of different tetraorganotins $\mathrm{R}_{4} \mathrm{Sn}$ towards $\mathrm{SOCl}_{2}$ decreases in the series $\mathrm{R}=n-\mathrm{C}_{4} \mathrm{H}_{9}>n$ $\mathrm{C}_{3} \mathrm{H}_{7}>\mathrm{C}_{2} \mathrm{H}_{5}>\mathrm{CH}_{3}>\mathrm{C}_{6} \mathrm{H}_{5} \mathrm{CH}_{2} \gg \mathrm{C}_{6} \mathrm{H}_{4} \mathrm{CH}_{3}$ [105].

The first diorganotin dihalide reported in the literature, $\mathrm{Et}_{2} \mathrm{SnI}_{2}$, was prepared by a direct reaction of EtI with tin foil (Eq. (19); R=Et, $\mathrm{X}=\mathrm{I}$ ) [1,106]

$\mathrm{Sn}+2 \mathrm{RX} \stackrel{160-180^{\circ} \mathrm{C}}{\longrightarrow} \mathrm{R}_{2} \mathrm{SnX}_{2}$

In general, the order in reactivity decreases in the series $\mathrm{R}=\mathrm{Me}>\mathrm{Et}>\mathrm{Pr}$ and $\mathrm{X}=\mathrm{I}>\mathrm{Br}>\mathrm{Cl}$. Only in the case of RI this reaction takes place at relatively low temperatures [107]. Moreover, the direct reaction of organic chlorides and bromides with metallic tin requires catalysts like magnesium [108,109], $\mathrm{HgCl}_{2}$ [110], hexamethyl phosphoric triamide (HMPT) [111,112], copper powder [113] or crown ethers [114]. An exception is benzyl chloride which can be reacted directly with $\mathrm{Sn}^{0}$ [94]. In particular the reaction mediated by copper powder and crown ethers (dicyclohexyl-18-crown-6 and dibenzo-18-crown-6) give high yields and high selectivities.

Smith and Rochow [113] demonstrated that a continuous flow of methyl chloride gas through a reactor charged with metallic tin and the copper powder catalyst at $315{ }^{\circ} \mathrm{C}$ afforded pure $\mathrm{Me}_{2} \mathrm{SnCl}_{2}$ upon cooling of the output gas. The proposed mechanism for this copper catalyzed reaction consists of the steps depicted in Scheme 5.

This reaction continues until tetra-substitution has occurred. Rearrangement of the methyl and chlorine groups at the reaction temperature $\left(315^{\circ} \mathrm{C}\right)$ then leads to the formation of dimethyltin dichloride almost exclusively.

For the synthesis of dialkyltin dichlorides with longer alkyl chains like $n$-butyl or $n$-octyl, crown ethers like dicyclohexyl-18-crown-6 and dibenzo-18-crown-6 have to be used as catalyst [114]. The reaction of metallic tin with $\mathrm{RX}(\mathrm{R}=n$ - $\mathrm{Bu}, n$-Oct; $\mathrm{X}=\mathrm{Cl}, \mathrm{Br})$ is carried out in DMF with butyl iodide as co-catalyst at a temperature range of $100-160{ }^{\circ} \mathrm{C}$. The selectivity of the reactions is excellent (95-99\%), even for the reactions carried out at $160^{\circ} \mathrm{C}$. It was suggested that butyl iodide and the crown ether assist in the nucleophilic reactions Eqs. (20) and (21) $(\mathrm{X}=\mathrm{Cl}, \mathrm{Br})$

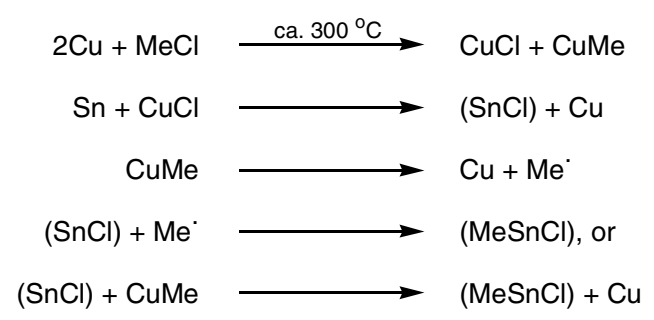

Scheme 5. Proposed steps for the copper catalyzed reaction of metallic tin with methyl chloride.
$\mathrm{RX}+\mathrm{I}^{-} \rightarrow \mathrm{RI}+\mathrm{X}^{-}$

$\mathrm{R}_{2} \mathrm{SnI}_{2}+2 \mathrm{X}^{-} \rightarrow \mathrm{R}_{2} \mathrm{SnX}_{2}+2 \mathrm{I}^{-}$

The alkyl iodide formed by the first nucleophilic substitution reaction of RX with $\mathrm{I}^{-}$(Eq. (20)), reacts readily in a direct reaction with metallic tin to yield $\mathrm{R}_{2} \mathrm{SnI}_{2}$. The second nucleophile substitution of $\mathrm{R}_{2} \mathrm{SnI}_{2}$ with $\mathrm{X}^{-}$(Eq. (21)) results in the formation of the desired $\mathrm{R}_{2} \mathrm{SnX}_{2}$.

Finally, Kocheshkov [115] demonstrated that tin(II) halides react with $\left(p-\mathrm{XC}_{6} \mathrm{H}_{4}\right)_{2} \mathrm{Hg}$ to give the aromatic tin dihalides $\left(p-\mathrm{XC}_{6} \mathrm{H}_{4}\right)_{2} \mathrm{SnX}_{2}$ and metallic mercury (Eq. (22); $\mathrm{X}=\mathrm{Cl}, \mathrm{Br}$ )

$\mathrm{SnX}_{2}+\mathrm{R}_{2} \mathrm{Hg} \rightarrow \mathrm{R}_{2} \mathrm{SnX}_{2}+\mathrm{Hg}$

The yields vary between $75 \%$ and $99 \%$, depending on the halide (X) used. Despite the good yields and selectivities, the use and the formation of toxic mercury compounds makes this method less attractive.

\section{Monoorganotin trihalides $\mathrm{RSnX}_{3}$}

Among the group of organotin halides, the monoorganotin trihalides are the most difficult ones to synthesize in a selective way. Since monoorganotin trihalides undergo a facile second substitution, reactions of $\mathrm{SnX}_{4}(\mathrm{X}=\mathrm{Cl}$ (preferred), $\mathrm{Br}$ or I) with an organometallic reagent like $\mathrm{RMgX}$ or $\mathrm{RLi}$, are not suitable. More selective methods for the synthesis of monoorganotin trihalides have therefore been developed. Most of these methods are specific for the organic group connected to tin.

One of the first methods reported is the Kocheshkov redistribution reaction of a tetraorganotin with a tin tetrahalide (Eq. (23); $\mathrm{X}=\mathrm{Cl}, \mathrm{Br}$ )

$\mathrm{R}_{4} \mathrm{Sn}+3 \mathrm{SnX}_{4} \rightarrow 4 \mathrm{RSnX}_{3}$

This reaction consists of three consecutive redistribution steps (Eqs. (24)-(26)) [116].

$$
\begin{aligned}
& \mathrm{R}_{4} \mathrm{Sn}+\mathrm{SnX}_{4} \rightarrow \mathrm{R}_{3} \mathrm{SnX}+\mathrm{RSnX}_{3} \\
& \mathrm{R}_{3} \mathrm{SnX}+\mathrm{SnX}_{4} \rightarrow \mathrm{R}_{2} \mathrm{SnX}_{2}+\mathrm{RSnX}_{3} \\
& \mathrm{R}_{2} \mathrm{SnX}_{2}+\mathrm{SnX}_{4} \rightarrow 2 \mathrm{RSnX}_{3}
\end{aligned}
$$

The use of this reaction is limited to $\mathrm{R}=$ vinyl [72,73], phenyl [97,117], mesityl [103], allyl [39-41] and acryl ester [118]. The third step (Eq. (26)) fails for $\mathrm{R}=$ alkyl. In practice, monoalkyltin trihalides are therefore prepared by a slightly modified version of the Kocheshkov redistribution resulting in the formation of $\mathrm{R}_{2} \mathrm{SnX}_{2}$ and $\mathrm{RSnX}_{3}$ in a one to two molar ratio (Eq. (27))

$\mathrm{R}_{4} \mathrm{Sn}+2 \mathrm{SnX}_{4} \rightarrow 2 \mathrm{RSnX}_{3}+\mathrm{R}_{2} \mathrm{SnX}_{2}$

Similarly to tetraorganotins, tetraorganogermanium compounds can react with one equivalent of $\mathrm{SnCl}_{4}$ under formation of $\mathrm{R}_{3} \mathrm{GeCl}$ and $\mathrm{RSnCl}_{3}$, respectively 
$[85,86]$. Using this method, $\mathrm{EtSnCl}_{3}$ and $n-\mathrm{BuSnCl}_{3}$ can be prepared in situ and in a quantitative yield. Unfortunately, the isolation and purification of the pure organotin trichlorides was not described. The reasonably large difference in boiling point between $\mathrm{R}_{3} \mathrm{GeCl}$ $\left(\mathrm{R}=\mathrm{Et}: 176^{\circ} \mathrm{C} ; n\right.$-Bu: $\left.269^{\circ} \mathrm{C}\right)$ and $\mathrm{RSnCl}_{3}(\mathrm{R}=\mathrm{Et}: 197$ ${ }^{\circ} \mathrm{C}, n$-Bu: $218^{\circ} \mathrm{C}$ ) suggests that isolation of pure $\mathrm{RSnCl}_{3}$ by fractional distillation is possible.

In a somewhat related redistribution reaction, $\mathrm{MeSnCl}_{3}$ can be prepared from $\mathrm{Me}_{2} \mathrm{SnCl}_{2}$ and $\mathrm{SbCl}_{5}$ (Eq. (28)) [100]

$$
\mathrm{R}_{2} \mathrm{SnCl}_{2}+\mathrm{SbCl}_{5} \rightarrow \mathrm{RSnCl}_{3}+\mathrm{RSbCl}_{4}
$$

However, for $\mathrm{R}=\mathrm{Ph}, \mathrm{SbCl}_{5}$ was found to be a too strong Lewis acid and as a result all phenyl groups were transferred from tin to antimony to give $\mathrm{Ph}_{2} \mathrm{SbCl}_{3}$ and $\mathrm{SnCl}_{4}$. For this substituent, the weaker Lewis acidic $\mathrm{BCl}_{3}$ was found to be more useful [100].

There are a number of studies which were directed to find suitable catalysts for the Kocheshkov redistribution reaction in Eq. (23) as well as for the redistribution reaction of $\mathrm{R}_{2} \mathrm{SnX}_{2}$ with $\mathrm{SnX}_{4}$ to give $\mathrm{RSnX}_{3}$ (Eq. (26)). Neumann and Burkhardt [116] reported the reaction of $\mathrm{Et}_{2} \mathrm{SnCl}_{2}$ with $\mathrm{SnCl}_{4}$ at $120-130{ }^{\circ} \mathrm{C}$ catalyzed by a $\mathrm{POCl}_{3} / \mathrm{P}_{2} \mathrm{O}_{5}$ mixture. At this temperature, no decomposition of $\mathrm{EtSnCl}_{3}$ takes place and after distillation, $\mathrm{EtSnCl}_{3}$ is obtained in $92 \%$ yield. The $\mathrm{POCl}_{3} / \mathrm{P}_{2} \mathrm{O}_{5}$ catalyst was also tested in the reaction of $\mathrm{Et}_{4} \mathrm{Sn}$ with three equivalents of $\mathrm{SnCl}_{4}$ (Eq. (23)) which resulted in full conversion of $\mathrm{Et}_{4} \mathrm{Sn}$ into $\mathrm{EtSnCl}_{3}$. However, in both reactions, a fivefold excess of $\mathrm{SnCl}_{4}$ is required to obtain good conversions. Moreover, a disadvantage of this method is the large amount of catalyst required (fourfold excess to $\mathrm{Et}_{2} \mathrm{SnCl}_{2}$ ). In fact, in these conversions the $\mathrm{POCl}_{3} / \mathrm{P}_{2} \mathrm{O}_{5}$ mixture can hardly be seen as a catalyst.

A few years later, Langer [119] demonstrated that $\mathrm{Me}_{2} \mathrm{SnCl}_{2}$ reacts with $\mathrm{SnCl}_{4}$ in polar reaction media like DMSO (dimethyl sulfoxide) affording MeSn$\mathrm{Cl}_{3}(\mathrm{DMSO})_{2}$ in $>90 \%$ yield. Under these conditions $\mathrm{Me}_{2} \mathrm{SnCl}_{2}$ presumably dissociates into $\left[\mathrm{Me}_{2} \mathrm{Sn}\right.$ $\left.(\mathrm{DMSO})_{x}\right]^{2+}$ cations and $\mathrm{Cl}^{-}$anions resulting in $\left[\mathrm{Me}_{2}-\right.$ $\left.\mathrm{Sn}(\mathrm{DMSO})_{x}\right]\left[\mathrm{SnCl}_{6}\right]$, which subsequently rearranges to $\left[\mathrm{MeSnCl}_{3}(\mathrm{DMSO})_{2}\right]$ (Scheme 6).

Through use of quaternary ammonium salts, Kugele and Parker [120] was able to catalyze the reaction of $\mathrm{Me}_{2} \mathrm{SnCl}_{2}$ with $\mathrm{SnCl}_{4}$ to give $\mathrm{MeSnCl}_{3}$ in almost quantitative yield. However, when dialkyltin dichlorides with longer alkyl chains were used, the yield of monoorganotin trichloride decreased dramatically. This is caused by decomposition of the desired product into $\mathrm{SnCl}_{2}$ and $\mathrm{RCl}$ at the high reaction temperatures required $\left(200^{\circ} \mathrm{C}\right)$.
Recently, we ourselves demonstrated the catalytic activity of cis-platinumdichloride bis(triarylphosphine) complexes in the reaction of dialkyltin dichlorides with tin tetrachloride affording monoorganotin halides in $67 \%(\mathrm{R}=n$-Hex $)$ to $88 \%(\mathrm{R}=\mathrm{Me}, \mathrm{Bu})$ yield. Eq. (26) [121]. With $0.1 \mathrm{~mol} \%$ of platinum catalyst, it was possible to obtain full conversion within $16 \mathrm{~h}$ at $110^{\circ} \mathrm{C}$ in non-coordinating solvents like toluene or xylene. For dialkyltin dichlorides possessing $\beta-\mathrm{H}$ atoms, also 10 $21 \%$ of $\mathrm{SnCl}_{2}$ was obtained as side product. However, the monoorganotin trichloride could be easily isolated by filtration (to remove the $\mathrm{SnCl}_{2}$ ) and subsequent evaporation of the solvent. The platinum-catalyzed Kocheshkov redistribution reaction is the first example of a method which is suitable for the selective preparation of monoalkyltin trichlorides in reasonably high yields.

In addition to $\mathrm{R}_{4} \mathrm{Sn}$ also other mild alkylation agents such as $\mathrm{R}_{4} \mathrm{Ge}, \mathrm{R}_{3} \mathrm{Al}\left(\mathrm{OR}_{2}^{\prime}\right), \mathrm{R}_{3} \mathrm{Al}\left(\mathrm{NR}_{3}^{\prime}\right)$ and mesitylcopper have been used as alkyl or aryl source.

As already discussed for the synthesis of $\mathrm{R}_{4} \mathrm{Sn}$, aluminum trialkyls $\left(\mathrm{R}_{3} \mathrm{Al}\right)$ can be used to substitute the halides in $\mathrm{SnCl}_{4}$. Buschhoff and Müller [122] showed that this reagent is also suitable for the selective monoalkylation of $\mathrm{SnCl}_{4}$. In this reaction, stoichiometric amounts of an ether complex $\mathrm{R}_{3} \mathrm{Al}\left(\mathrm{OR}_{2}^{\prime}\right)$ or a tertiary amine complex $\mathrm{R}_{3} \mathrm{Al}\left(\mathrm{NR}_{3}^{\prime}\right)$ were used to reduce the alkylating power of the aluminum reagent (Eq. (29))

$$
\begin{aligned}
& 3 \mathrm{SnCl}_{4}+\mathrm{R}_{3} \mathrm{Al}\left(\mathrm{OR}_{2}^{\prime}\right) \text { or } \mathrm{R}_{3} \mathrm{Al}\left(\mathrm{NR}_{3}^{\prime}\right) \\
& \quad \rightarrow 3 \mathrm{RSnCl}_{3}+\mathrm{AlCl}_{3}\left(\mathrm{OR}_{2}^{\prime}\right) \text { or } \mathrm{AlCl}_{3}\left(\mathrm{NR}_{3}^{\prime}\right)
\end{aligned}
$$

This reaction is performed under rather mild conditions $\left(20-70{ }^{\circ} \mathrm{C}\right)$ affording, for example, $n$ - $\mathrm{BuSnCl}_{3}$ and $n$ OctylSnCl $\mathrm{Sn}_{3}$ in a $85-90 \%$ yield. The yields can be slightly improved by using aluminum alcoholates $\left[\mathrm{R}_{2} \mathrm{Al}\left(\mathrm{OR}^{\prime}\right)\right]_{x}$ instead of $\mathrm{R}_{3} \mathrm{Al}\left(\mathrm{OR}_{2}^{\prime}\right.$ ) (Eq. (30)) [123].

$$
\begin{aligned}
& 2 \mathrm{SnCl}_{4}+1 / x\left[\mathrm{R}_{2} \mathrm{Al}\left(\mathrm{OR}^{\prime}\right)\right]_{x} \\
& \quad \rightarrow 2 \mathrm{RSnCl}_{3}+1 / y\left[\mathrm{AlCl}_{2}\left(\mathrm{OR}^{\prime}\right)\right]_{y}
\end{aligned}
$$

From an economical point of view, the latter reactions is less interesting because only two alkyl groups per molecule of $\left[\mathrm{R}_{2} \mathrm{Al}\left(\mathrm{OR}^{\prime}\right)\right]_{x}$-reagent are transferred.

The use of mesitylcopper was investigated by Jäkle and Manners [102] as an alternative for the less selective organolithium and Grignard reagents or organo-mercury, -tin and -zinc compounds. [CuMes] $]_{5}$ (toluene) reacts easily with $\mathrm{SnCl}_{4}$ to yield $\mathrm{MesSnCl}_{3}$ in a $92 \%$ isolated yield. Without any further purification, this compound is already obtained in $97 \%$ purity underlining the high selectivity of this reagent.

$$
\mathrm{Me}_{2} \mathrm{SnCl}_{2}+\mathrm{SnCl}_{4} \underset{\mathrm{DMSO}}{\longrightarrow}\left[\mathrm{Me}_{2} \mathrm{Sn}(\mathrm{DMSO})_{x}\right]\left[\mathrm{SnCl}_{6}\right] \longrightarrow 2\left[\mathrm{MeSnCl}_{3}(\mathrm{DMSO})_{2}\right]
$$


The direct reaction or oxidative addition reaction of a tin(II) halide with an organic halide, in principle, provides an efficient and selective one-step synthesis for monoorganotin trihalides (Eq. (31))

$$
\mathrm{SnX}_{2}+\mathrm{RX} \rightarrow \mathrm{RSnX}_{3}
$$

This reaction does not proceed selectively without a catalyst. Organic disulfides, primary amines, quaternary ammonium halides, phosphonium halides and trialkylantimony have been employed as catalysts to obtain reasonable yields of $\mathrm{RSnCl}_{3}$ [124]. Especially trialkylantimony catalysts were found to give good results in the case of alkyltin tribromides; $n$-OctSnBr 3 and $n$ $\mathrm{BuSnBr}_{3}$ were obtained in $85 \%$ yield. This method was found to be less suitable for the preparation of alkyltin trichlorides as both the rate of the reaction and the yield decreased dramatically. In practice, this approach is also less useful for large scale application because of the high loading of a highly toxic trialkylantimony catalyst and the fact that this conversion is limited to monoorganotin bromides.

The direct reaction of allyl chloride with $\mathrm{SnCl}_{2}$ is catalyzed by phenantroline palladium dichloride or dimethyl complexes affording allyltin trichloride in up to $83 \%$ yield [125].

Matsuda and co-workers prepared $\mathrm{MeSnCl}_{3}$ in $95 \%$ yield by reacting $\mathrm{SnCl}_{2}$ with $\mathrm{MeCl}$ in the presence of catalytic amounts of $I_{2}$ and magnesium (Eq. (32)) [126]. An excess of $\mathrm{MeCl}$ was necessary to prevent formation of side-products like $\mathrm{Me}_{2} \mathrm{SnCl}_{2}$. The patent application did not mention the scope of the method

$$
\mathrm{SnCl}_{2}+\mathrm{MeCl} \stackrel{\mathrm{Mg}, \mathrm{I}_{2}}{\longrightarrow} \mathrm{MeSnCl}_{3}
$$

Subsequent to the work on the direct reaction, several researchers investigated the hydrostannation of alkenes with trihalostannanes $\mathrm{HSnX}_{3}[127-130]$. $\mathrm{HSnCl}_{3}$, which itself is unstable, was prepared in situ from $\mathrm{HCl}$ with $\mathrm{SnCl}_{2}$ in a polar solvent like $\mathrm{Et}_{2} \mathrm{O}$, THF, DME or methanol (Eq. (33)) [131].

$$
\mathrm{SnCl}_{2}+\mathrm{HCl} \stackrel{\text { solvent }}{\rightleftharpoons} \mathrm{HSnCl}_{3}(\text { solvent })_{2}
$$

More recently, Nakahira et al. [132] demonstrated that stable and pure $\mathrm{HSnCl}_{3}\left(\mathrm{Et}_{2} \mathrm{O}\right)_{2}$ can be prepared from $\mathrm{SnCl}_{2}$ with $\mathrm{Me}_{3} \mathrm{SiCl}$ in $\mathrm{Et}_{2} \mathrm{O}$.

Addition of $\alpha$-olefins, such as 1-octene, to a solution of $\mathrm{HSnCl}_{3}\left(\mathrm{Et}_{2} \mathrm{O}\right)_{2}$ at $15{ }^{\circ} \mathrm{C}$ results in the formation of traces of octyltin trichloride [129]. Similar results are obtained for other $\alpha$-olefins like propene and butene.

$$
\begin{gathered}
\mathrm{ROC}(\mathrm{O}) \mathrm{CH}=\mathrm{CH}_{2}+\mathrm{HCl}+\mathrm{SnCl}_{2} \\
\underset{\mathrm{Et}_{2} \mathrm{O}}{\longrightarrow} \mathrm{ROC}(\mathrm{O}) \mathrm{CH}_{2} \mathrm{CH}_{2} \mathrm{SnCl}_{3}
\end{gathered}
$$

However, with $\alpha, \beta$-unsaturated carbonyl compounds such as methyl acrylate $[128,129]$ and itaconic acid esters [127] in which the $\mathrm{C}=\mathrm{C}$ double bond is activated, full conversion to the monoorganotin trichloride is possible within $3.5 \mathrm{~h}$ at room temperature (Eq. (34)). Depending on the type of acrylic ester, the yield varies between $60 \%$ and $99 \%$.

Mechanistic studies performed with $\mathrm{DCl}$, resulted in the postulation of the mechanism depicted in Scheme 7.

The first steps in this mechanism involves the formation of the $\mathrm{HCl}$ adduct of the $\alpha, \beta$-unsaturated carbonyl compound. and the interaction with $\mathrm{SnCl}_{2}$ to give the $\mathrm{HSnCl}_{3}$ adduct. This intermediate rearranges by attack of $\mathrm{Cl}_{3} \mathrm{Sn}^{-}$at the $\beta$-carbon. Spectroscopic data (IR and NMR) $[129,130]$ and an X-ray crystallographic structure of (4-ethoxy-4-oxobutyl)tin trichloride [133] showed a strong interaction between the carbonyl lonepair electrons and the tin center. $\alpha, \beta$-Unsaturated ketones and aldehydes react in a similar way to yield the corresponding $\beta$-trichlorostannyltins which serve as starting material for the preparation of $\beta$-trialkylstannyl ketones [132] and other $\alpha$-methylene-substituted ketones and aldehydes [134].

As already mentioned, the reaction of $\mathrm{HSnCl}_{3}$ with $\alpha$ olefins, affords rather poor yields $(<10 \%)$ of monoorganotin trichlorides. Motivated by this and other work [135], Chee started to investigate the use of $\left[\eta^{5}\right.$ $\left.\mathrm{Cp}_{2} \mathrm{Zr}(\mathrm{H}) \mathrm{Cl}\right]$ in the reaction of 1-octene with $\mathrm{SnCl}_{4}$ [136]. The hydrido zirconocene chloride is known to react with olefins to form alkylzirconium(IV) complexes (Eq. (35)) [135b,135c,135d]. They found that in situ

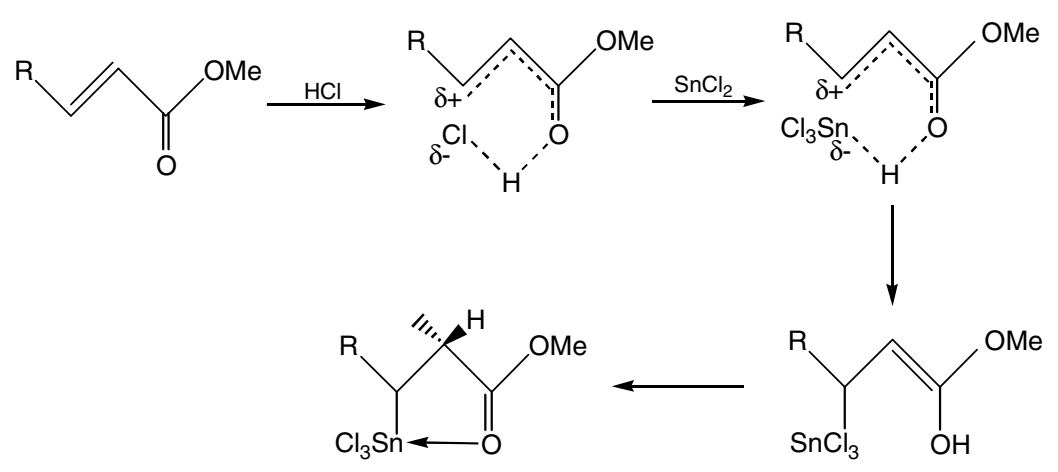

Scheme 7. Proposed mechanism for the reaction of $\mathrm{HCl}$ and $\mathrm{SnCl}_{2}$ with $\alpha, \beta$-unsaturated carbonyl compounds according to [129]. 
prepared $\left[\eta^{5}-\mathrm{Cp}_{2} \mathrm{Zr}\right.$ (octyl)Cl] reacts with $\mathrm{SnCl}_{4}$ under formation of $n$-OctylSnCl 3 and $\left[\eta^{5}-\mathrm{Cp}_{2} \mathrm{ZrCl}_{2}\right]$ (Eq. (36))

$$
\begin{aligned}
& {\left[\left(\eta^{5}-\mathrm{C}_{2} \mathrm{H}_{5}\right)_{2} \mathrm{ZrHCl}\right]+1 \text {-octene }} \\
& \quad \rightarrow\left[\left(\eta^{5}-\mathrm{C}_{2} \mathrm{H}_{5}\right)_{2} \mathrm{Zr}(1 \text {-octyl }) \mathrm{Cl}\right] \\
& {\left[\left(\eta^{5}-\mathrm{C}_{2} \mathrm{H}_{5}\right)_{2} \mathrm{Zr}(1 \text {-octyl }) \mathrm{Cl}\right]+\mathrm{SnCl}_{4}} \\
& \quad \rightarrow\left[\left(\eta^{5}-\mathrm{C}_{2} \mathrm{H}_{5}\right)_{2} \mathrm{ZrCl}_{2}\right]+n \text {-Octyl } \mathrm{SnCl}_{3}
\end{aligned}
$$

In this way, $n$-OctSnCl${ }_{3}$ could be prepared in $81 \%$ yield and only trace amounts of $n$-Oct $\mathrm{SnCl}_{2}$ were detected by TLC analysis.

\section{Concluding remarks}

Most tetraorganotins are prepared in high yields and with good selectivity by a reaction of a Grignard reagent with $\mathrm{SnCl}_{4}$. They are the commonly used starting material for the synthesis of organotin halides through a Kocheshkov redistribution reaction with a suitable tin(IV) halide. This reaction affords diorgano- or triorganotin halides in high yields. For high yield synthesis of monoorganotin halides, which are relevant because of their use for the deposition of tin oxide coatings on glass, this reaction is limited to allyl, vinyl and phenyltins. Monoalkyltin trihalides with long alkyl groups like $n$-butyl and $n$-octyl are more challenging to prepare. In recent years, several alternative methods for preparation of these alkyltin trihalides such as, the alkylation of $\mathrm{SnCl}_{4}$ with $\mathrm{R}_{3} \mathrm{Al}\left(n-\mathrm{Bu}_{2} \mathrm{O}\right)$, the trialkylantimony-catalyzed reaction of organic halides with tin(II) halides and the platinumcatalyzed Kocheshkov redistribution reaction of dialkyltin dichlorides with tin tetrachloride, have become available. Of these methods, the platinum-catalyzed reaction appears to be the most attractive because of its scope, low catalyst loading, facile product separation and the mild condition under which it can be operated.

\section{References}

[1] (a) E. Frankland, Liebigs Ann. Chem. 71 (1849) 171;

(b) E. Frankland, Liebigs Ann. Chem. 71 (1849) 212.

[2] A.I. Sadiki, D.T. Williams, Chemosphere 32 (1996) 2389.

[3] G. Ayrey, B.C. Head, R.C. Poller, Macromol. Rev. 8 (1974) 1.

[4] G.J.M. van der Kerk, J.G.A. Luitjen, J. Appl. Chem. 4 (1954) 314.

[5] C.J. Evans, R. Hill, J. Oil Colour Chem. Assoc. 64 (1998) 215.

[6] B.A. Richardson, T.R.G. Cox, Tin Its Uses 102 (1974) 6.

[7] F.C. Lu, M.L. Dourson, Toxicol. Lett. 64/65 (1992) 783.

[8] D. Liu, R.J. Maguire, Y.L. Lau, G.J. Pacepavicius, H. Okamaru, I. Aoyama, Water Res. 31 (1997) 2363.

[9] N. Voulvoulis, M.D. Scrimshaw, J.N. Lester, Appl. Organomet. Chem. 13 (1999) 135.

[10] (a) R.J. Maguire, Water Qual. Res. J. Can. 26 (1991) 43;

(b) K. Frent, Crit. Rev. Toxicol. 26 (1996) 1;

(c) J. White, J.M. Tobin, J.J. Cooney, Can. J. Microbiol. 45 (1999) 541 ;

(d) M. Hoch, Appl. Geochem. 16 (2001) 719.
[11] (a) K. Fent, M.D. Müller, Environ. Sci. Technol. 25 (1991) 489; (b) A. Weidenhaupt, C. Arnold, S.R. Müller, S.B. Haderlein, R.P. Schwarzenbach, Environ. Sci. Technol. 31 (1997) 2603;

(c) H. Harino, M. Fukushima, Y. Yamamoto, S. Kawai, N. Miyazaki, Environ. Pollut. 101 (1998) 209;

(d) M. Berg, C.D. Arnold, S.R. Müller, J. Mühlemann, R.P. Schwarzenbach, Environ. Sci. Technol. 35 (2001) 3151.

[12] (a) E.A. Clark, R.M. Sterritt, J.N. Lester, Environ. Sci. Technol. 22 (1988) 600;

(b) R.J. Maguire, Wat. Sci. Technol. 25 (1992) 125;

(c) P.H. Dowson, D. Pershke, J.M. Bubb, J.N. Lester, Environ. Pollut. 76 (1992) 259;

(d) P.H. Dowson, J.M. Bubb, J.N. Lester, Mar. Pollut. Bull. 24 (1992) 492.

[13] P.E. Gibbs, G.W. Bryan, J. Mar. Biol. Ass 66 (1986) 767.

[14] Abstract of the Diplomatic Conference of IMO, October 5th, 2001, IMO headquarters, London.

[15] C.J. Evans, Tin and its Uses 132 (1982) 5.

[16] P.J. Smith, Chemistry of Tin, second ed., Chapmann and Hall, London, 1998.

[17] G.A. Davies, Comprehensive Organometallic Chemistry, vol. 6, second ed., Pergamon, New York, 1995, pp. 217-303.

[18] Data according to the Material Safety Data Sheets (MSDS). Available from http://www.setonresourcecenter.com/MSDS/ index.html.

[19] D.W. Allen, S. Brooks, J. Unwin, J.D. McGuinness, Appl. Organomet. Chem. 1 (1987) 311.

[20] K. Fent, Sci. Total Environ. 185 (1996) 151.

[21] L. Gmelin, in: Handbuch der Anorganische Chemie, vols. 1-6, Springer Verlag, Berlin, 1972-1978, Part C.

[22] A. Bokranz, H. Plum, Fortschr. Chem. Forsch. 16 (1971) 365.

[23] K. Moedritzer, Organomet. Chem. Rev. 1 (1966) 179.

[24] R.K. Ingham, S.D. Rosenberg, H. Gilman, Chem. Rev. 60 (1960) 459.

[25] E.I. Becker, M. Tsutsui, in: Organometallic Reactions, vol. 2, Wiley-Interscience, New York, 1970.

[26] W.P. Neumann, The Organic Chemistry of Tin, Wiley, New York, 1970.

[27] W.F. Edgell, C.H. Ward, J. Am. Chem. Soc. 76 (1954) 1169.

[28] K.V. Vijayaraghavan, J. Indian Chem. Soc. 22 (1945) 135.

[29] H.C. Clark, C.J. Willis, J. Am. Chem. Soc. 82 (1960) 1888.

[30] I. Földesi, Acta Chim. Acad. Sci. Hung. 45 (1965) 237.

[31] H. Zimmer, H. Gold, Chem. Ber. 89 (1956) 712.

[32] G.J.M. van der Kerk, J.G.A. Luijten, Org. Synth. 36 (1956) 86.

[33] A. Saitow, E.G. Rochow, D. Seyerferth, J. Org. Chem. 23 (1958) 116.

[34] Solvay \& Cie; Fr. Pat. 1449872, July 11, 1966.

[35] B. Bogdanovic, P. Bons, S. Konstantinovic, M. Schwickardi, U. Westeppe, Chem. Ber. 126 (1993) 1371.

[36] J.G. Natoli, M \& T Chemicals Inc., Neth. Pat. 6507716, June 16, 1964.

[37] M.J. Cuthbertson, P.R. Wells, J. Organomet. Chem. 216 (1981) 331.

[38] S.D. Rosenberg, A.J. Gibbons Jr., H.E. Ramsden, J. Am. Chem. Soc. 79 (1957) 2137.

[39] M. Fishwick, G.H. Wallbridge, J. Organomet. Chem. 25 (1970) 69.

[40] Y. Naruta, Y. Nishigaichi, K. Maruyama, Tetrahedron 45 (1989) 1067.

[41] S.E. Denmark, T. Wilson, T.M. Willson, J. Am. Chem. Soc. 110 (1988) 984.

[42] H. Ballczo, H. Schniffner, Z. Anal. Chem. 152 (1956) 3.

[43] P. Pfeiffer, K. Schnurmann, Dtsch. Chem. Ges. 37 (1904) 319.

[44] W. Schacht, D. Kaufmann, Chem. Ber. 120 (1987) 1331.

[45] R.K. Sharma, C.P. Sharma, A. Sharma, J. Indian Chem. Soc. 64 (1987) 205.

[46] G.J.M. van der Kerk, J.G.A. Luijten, J. Appl. Chem. 4 (1954) 301. 
[47] G.J.M. van der Kerk, J.G.A. Luijten, J. Appl. Chem. 7 (1957) 369 [48] D.W. Owen, R.C. Poller, J. Organomet. Chem. 255 (1983) 173.

[49] T.M. Aminabhavi, N.S. Biradar, S.B. Patil, D.E. Hoffman, Inorg. Chim. Acta 135 (1987) 139.

[50] T.M. Aminabhavi, N.S. Biradar, S.B. Patil, D.E. Hoffman, Inorg. Chim. Acta 108 (1985) L31.

[51] D.N. Waters, L.A. Woodward, Proc. R. Soc. Lond., Ser. A 246 (1958) 119.

[52] R.F. Chambers, P.C. Scherer, J. Am. Chem. Soc. 48 (1926) 1055.

[53] J.C. Egmond, J.G.A. Janssen, J.G.A. Luijten, G.J.M. van der Kerk, G.M. Want, J. Appl. Chem. 12 (1962) 17.

[54] (a) K. Ziegler, Brit. Pat. 923179, April 10, 1963; (b) K. Ziegler, W.P. Neumann, Ger. Pat. 1157617, April 10, 1963.

[55] W.P. Neumann, Liebigs Ann. Chem. 653 (1962) 157.

[56] Y. Takeda, T. Okuyama, T. Fueno, J. Fukukawa, Macromol. Chem. (1964) 209.

[57] W.P. Neumann, H. Niermann, R. Sommer, Leibigs Ann. Chem. 659 (1962) 27.

[58] H. Jenkner, Chem. -Ztg. 86 (1962) 563.

[59] H. Jenkner, H.W. Schmidt, Ger. Pat. 1048275, Jan. 8, 1959.

[60] L.I. Zakharin, O.Y. Okhlobystin, B.N. Strunin, J. Appl. Chem. USSR 36 (1963) 1969.

[61] W. Sundermeyer, W. Verbeek, Ger. Pat. 1239687, Nov 15, 1967.

[62] W. Sundermeyer, W. Verbeek, Angew. Chem. 78 (1966) 107.

[63] K. Sisido, S. Kozima, J. Organomet. Chem. 11 (1968) 503.

[64] V.V. Sharutin, O.K. Sharutina, V.S. Senchurin, T.A. Kovaleva, V.I. Shcherbakov, E.N. Gladyshev, Russ. J. Gen. Chem. 70 (2000) 64.

[65] C. Eaborn, J.A. Waters, J. Chem. Soc. (1962) 1131.

[66] H.G. Kuivila, O.F. Beumel Jr., J. Am. Chem. Soc. 80 (1958) 3250.

[67] D. Kovala-Demertzi, P. Tauridou, J.M. Tsangaris, A. Moukarika, Main Group Met. Chem. 16 (1993) 315.

[68] H.H. Anderson, Inorg. Chem. 1 (1962) 647.

[69] I.L. Marr, D. Rosales, J.L. Wardell, J. Organomet. Chem. 349 (1988) 65.

[70] G.J.M. van den Kerk, J.G.A. Luijten, J. Appl. Chem. 6 (1956) 56.

[71] S.D. Rosenberg, E. Debreczeni, E.L. Weinberg, J. Am. Chem. Soc. 83 (1959) 972.

[72] D. Seyferth, F.G.A. Stone, J. Am. Chem. Soc. 79 (1957) 515.

[73] S.D. Rosenberg, A.J. Gibbons Jr., J. Am. Chem. Soc. 79 (1957) 2138.

[74] (a) H. Zimmer, O.A. Homberg, M. Jayawant, J. Org. Chem. 31 (1966) 3857 ; (b) W.T. Reichle, Inorg. Chem. 5 (1966) 87.

[75] M. Gielen, Acc. Chem. Res. 6 (1973) 198; M. Gielen, Moakhtar-Jamai, Bull. Soc. Chim. Belg. 84 (1975) 197.

[76] R.M. Lequan, M. Lequan, Tetrahedron Lett. 22 (1981) 1323.

[77] M.H. Abraham, J.A. Hill, J. Organomet. Chem. 7 (1967) 11.

[78] H. Gilman, H.W. Melvin Jr., J. Am. Chem. Soc. 71 (1949) 4050.

[79] C.K. Banks, US Pat. 3297732, January 10, 1967.

[80] G.J.M. van der Kerk, J.G. Noltes, J.G.A. Luijten, J. Appl. Chem. 7 (1957) 366.

[81] J. D’Ans, H. Zimmer, Chem. Ber. 85 (1952) 585.

[82] G.F. Smith, H.G. Kuivila, R. Simon, L. Sultan, J. Am. Chem. Soc. 103 (1981) 833.

[83] G.J.M. van der Kerk, J.G.A. Luijten, J. Appl. Chem. 6 (1956) 93.

[84] K.A. Kozeschkov, Ber. 66 (1933) 1661.

[85] G.A. Luijten, F. Rijkens, Rec. Trav. Chim. 83 (1964) 857.

[86] E.J. Bulten, W. Drenth, J. Organomet. Chem. 61 (1973) 179.

[87] E. Krause, Ber. Dtsch. Chem. Ges. 51 (1918) 912.

[88] T.N. Srivastava, S.K. Tandon, Indian J. Appl. Chem. 26 (1963) 171.

[89] G. Bähr, Z. Anorg. Allg. Chem. 256 (1948) 107.

[90] D.A. Armitage, A. Tarassoli, Inorg. Chem. 14 (1975) 1210.

[91] S. Fukuzumi, T. Kitano, Inorg. Chem. 29 (1990) 2558.

[92] G. van Koten, C.A. Schaap, J.G. Noltes, J. Organomet. Chem. 99 (1975) 157.

[93] K. Sisido, S. Kozima, T. Hanada, J. Organomet. Chem. 9 (1967) 99.
[94] K. Sisido, Y. Takeda, Z. Kinugawa, J. Am. Chem. Soc. 83 (1961) 538.

[95] G. van Koten, J.G. Noltes, J. Am. Chem. Soc. 98 (1976) 5393.

[96] K.A. Kozeschkov, Ber. 62 (1929) 996.

[97] H. Gilmann, L.A. Gist Jr., J. Org. Chem. 22 (1957) 368.

[98] B.G. Kushlefsky, M \& T Chemicals; Brit. Pat. 1096922, December 29, 1967.

[99] M. Buschhoff, Ger. Pat. 0158163, March 16, 1985.

[100] K.B. Dillon, G.F. Hewitson, Polyhedron 3 (1984) 957.

[101] A.V. Grosse, J.M. Mavity, J. Org. Chem. 5 (1940) 106

[102] F. Jäkle, I. Manners, Organometallics 18 (1999) 2628.

[103] P. Brown, M.F. Mahon, K.C. Molloy, J. Organomet. Chem. 435 (1992) 265.

[104] V. Bade, F. Huber, J. Organomet. Chem. 24 (1970) 387.

[105] S.P. Narula, R.K. Sharama, S. Lata, R. Walia, Indian J. Chem., Sect. A: Inorg. Phys. Theor. Anal. 22 (1983) 246.

[106] E. Frankland, Liebigs Ann. Chem. 85 (1853) 329.

[107] (a) V. Oakes, R.E. Hutton, J. Organomet. Chem. 3 (1965) 472; (b) V. Oakes, R.E. Hutton, J. Organomet. Chem. 6 (1966) 133.

[108] S. Matsuda, H. Matsuda, Bull. Chem. Soc. Jpn. 35 (1962) 208.

[109] T. Yatagai, S. Matsuda, H. Matsuda, US Pat. 3085102, April 9, 1963.

[110] C. Boga, D. Savoia, E. Tagliavini, C. Trombini, A. UmaniRonchi, J. Organomet. Chem. 353 (1988) 177.

[111] E.J. Bulten, F. Verbeek, US Pat. 4044035, August 23, 1977.

[112] F. Verbeek, E.J. Bulten, J.W.G. van den Hurk, US Pat. 4049689 , September 20, 1977.

[113] A.C. Smith Jr., E.G. Rochow, J. Am. Chem. Soc. 75 (1953) 4103.

[114] R. Ugo, A. Chiesa, A. Fusi, J. Organomet. Chem. 330 (1987) 25.

[115] K.A. Kozeschkov, Ber. 64 (1931) 628.

[116] W.P. Neumann, G. Burkhardt, Liebigs Ann. Chem. 663 (1963) 11.

[117] H. Zimmer, H.-W. Sparmann, Chem. Ber. 87 (1954) 645.

[118] J.W. Burley, Ger. Pat. 2702363, July 28, 1977.

[119] H.G. Langer, Tetrahedron Lett. 1 (1967) 43.

[120] T. Kugele, D.H. Parker, US Pat. 3862198, January 21, 1975.

[121] S. Thoonen, B.-J. Deeman, G. van Koten, Chem. Commun. (2001) 1840.

[122] M. Buschhoff, K.H. Müller, US Pat. 3894066, July 8, 1975.

[123] M. Buschhoff, K.H. Müller, US Pat. 3994944, November 30, 1976.

[124] E.J. Bulten, J. Organomet. Chem. 97 (1975) 167.

[125] S.H.L. Thoonen, B.-J. Deelman, G. van Koten, Tetrahedron 59 (2003) 10261

[126] S. Matsuda, H. Kudara, US Pat. 4046791, September 6, 1977.

[127] H. Korbanka, F. Scheidl, Ger. Pat. 2850150, May 29, 1980.

[128] R.E. Hutton, V. Oakes, J. Burley, US Pat. 4105684, August 8, 1978.

[129] R.E. Hutton, J.W. Burley, J. Organomet. Chem. 156 (1978) 369.

[130] J.W. Burley, R.E. Hutton, V. Oakes, J. Chem. Soc., Chem. Commun. 20 (1976) 803.

[131] (a) O.M. Nefedov, S.P. Kolesnikov, V.I. Scheichenko, Y.N. Sheinker, Dokl. Akad. Nauk. Ussr. 162 (1965) 589; (b) E.J. Bulten, J.W.G. Hurk, J. Organomet. Chem. 162 (1978) 161; (c) A. Tzsachach, W. Uhlig, K. Kellner, J. Organomet. Chem. 266 (1984) 17.

[132] H. Nakahira, I. Ryu, A. Ogawa, N. Kambe, N. Sonoda, Organometallics 9 (1990) 277.

[133] R.A. Howie, E.S. Paterson, J.L. Wardell, J. Organomet. Chem. 259 (1983) 71.

[134] H. Nakahira, I. Ryu, M. Ikebe, Y. Oku, A. Ogawa, N. Kambe, N. Sonoda, S. Murai, J. Org. Chem. 57 (1992) 17.

[135] (a) A.G. Brook, G.J.D. Peddle, J. Am. Chem. Soc. 85 (1963) 1869; (b) C. Eaborn, R.E.E. Hill, P. Simpson, J. Organomet. Chem. 15 (1968) P1;

J. Organomet. Chem. 37 (1972) 267, and 275;

(c) E.O. Fischer, H.J. Beck, Chem. Ber. 104 (1971) 3101;

(d) F. Carré, R.J.P. Corriu, J. Organomet. Chem. 65 (1974) 349.

[136] V.G. Kumur Das, O.G. Chee, J. Organomet. Chem. 321 (1987) 335. 